NBER WORKING PAPER SERIES

\title{
THE STABILITY OF LARGE EXTERNAL IMBALANCES: THE ROLE OF RETURNS DIFFERENTIALS
}

\author{
Stephanie E. Curcuru \\ Tomas Dvorak \\ Francis E. Warnock \\ Working Paper 13074 \\ http://www.nber.org/papers/w13074
NATIONAL BUREAU OF ECONOMIC RESEARCH
1050 Massachusetts Avenue \\ Cambridge, MA 02138
}

May 2007

This paper will also be circulated as Federal Reserve IFDP\#894. The views in this paper are solely the responsibility of the author(s) and should not be interpreted as reflecting the views of the Board of Governors of the Federal Reserve System or of any other person associated with the Federal Reserve System. We thank for helpful comments Carol Bertaut, Ricardo Caballero, Charles Engel, Kristen Forbes, Gian-Maria Milesi-Ferretti, Cedric Tille, Charles Thomas, Ralph Tryon, Eric van Wincoop, Jon Wongswan, and seminar participants at the Dallas Fed. Warnock thanks the Darden School Foundation for its generous support. The views expressed herein are those of the author(s) and do not necessarily reflect the views of the National Bureau of Economic Research.

(C) 2007 by Stephanie E. Curcuru, Tomas Dvorak, and Francis E. Warnock. All rights reserved. Short sections of text, not to exceed two paragraphs, may be quoted without explicit permission provided that full credit, including $\odot$ notice, is given to the source. 
The Stability of Large External Imbalances: The Role of Returns Differentials

Stephanie E. Curcuru, Tomas Dvorak, and Francis E. Warnock

NBER Working Paper No. 13074

May 2007

JEL No. F3

\begin{abstract}
$\underline{\text { ABSTRACT }}$
Were the U.S. to persistently earn substantially more on its foreign investments ("U.S. claims") than foreigners earn on their U.S. investments ("U.S. liabilities"), the likelihood that the current environment of sizeable global imbalances will evolve in a benign manner increases. However, utilizing data on the actual foreign equity and bond portfolios of U.S. investors and the U.S. equity and bond portfolios of foreign investors, we find that the returns differential of U.S. claims over U.S. liabilities is essentially zero. Ending our sample in 2005, the differential is positive, whereas through 2004 it is negative; in both cases the differential is statistically indecipherable from zero. Moreover, were it not for the poor timing of investors from developed countries, who tend to shift their U.S. portfolios toward (or away from) equities prior to the subsequent underperformance (or strong performance) of equities, the returns differential would be even lower. Thus, in the context of equity and bond portfolios we find no evidence that the U.S. can count on earning more on its claims than it pays on its liabilities.

Stephanie E. Curcuru

Board of Governors

of the Federal Reserve System

20th Street and Constitution Avenue, NW

Washington DC 20551

stephanie.e.curcuru@ frb.gov

Tomas Dvorak

Union College

Department of Economics

Social Sciences Bldg 215

Schenectady, NY 12308

dvorakt@union.edu

Francis E. Warnock

Darden Business School

University of Virginia

Charlottesville, VA 22906-6550

and NBER

warnockf@darden.virginia.edu
\end{abstract}




\section{Introduction}

Substantial global imbalances are a central influence on the current international economic order. Whether and how these imbalances might unravel have important implications for economic stability in general and for the future path of the U.S. dollar in particular.

One aspect of this situation that has attracted a great deal of attention recently is the returns differential, the difference between the rate that the United States pays foreigners on its international liabilities and that which it earns on its foreign claims. It is presumed that the returns differential is positive, in large part because of the striking finding in Gourinchas and Rey (2006a) that over the past three decades U.S. investors' returns on foreign equities and bonds have exceeded foreigners' U.S. returns by 6.21 percent and 3.72 percent, respectively, per year.

Understanding what is behind this substantial positive returns differential is important for many reasons. A positive U.S. returns differential vis-à-vis the rest of the world would be a source of stability in the current system. For example, in the model of Cavallo and Tille (2006) a more positive returns differential impacts the dynamics of current account adjustment in a way that lessens the probability of a disorderly unraveling of global imbalances. Similarly, Hausmann and Sturtzeneger (2006) argue that global imbalances are more sustainable the more permanent is the returns differential. Should a positive returns differential persist, the likelihood of a relatively benign continuation of global imbalances would increase. Should a positive returns differential cease, one barrier to an unsavory adjustment in the world economic order would be removed. Any return differential, however large or small, becomes ever more important because of the steady increase in the size of gross claims and gross liabilities positions (Lane and Milesi-Ferretti, 2006; Tille, 2005).

Understanding what is behind the returns differential is important for another reason: Theoretical work is rapidly progressing without a solid understanding of what has driven the differential. The returns differential figures prominently in the models of Mendoza, Quadrini and Rios-Rull (2006), Ghironi, Lee, and Rebucci (2006), Devereux and Saito (2006), and Obstfeld 
and Rogoff (2005). In the model of Tille and van Wincoop (2007), a persistent returns differential is shown not to have an important role and the authors sound almost apologetic in noting that their "model can therefore not account for empirical findings by Gourinchas and Rey (2006b) that net external debt is to some extent financed by differences in expected returns" (Tille and van Wincoop 2007, page 31). Clearly, the presumption of a substantial and persistent positive returns differential is influencing theoretical work, making it even more important to examine the determinants of this differential.

Existing work points to two sources for the differential. The first is the difference in the composition of U.S. claims and liabilities: U.S. claims consist mostly of high-return equity, while U.S. liabilities consist mostly of low-return debt (Obstfeld and Rogoff 2005, Gourinchas and Rey 2006a, Lane and Milesi-Ferretti 2005b and Meissner and Taylor 2006). The other is that U.S investors earn relatively higher returns on their cross-border investments within each asset class. As noted, Gourinchas and Rey (2006a) find that over the past three decades U.S. investors' returns on both foreign equities and foreign bonds have substantially exceeded foreigners' U.S. returns in those asset classes.

Our findings can be easily summarized: We find no returns differential. For our sample (January 1994 through December 2005), the returns differential is positive 5.6 basis points per month but statistically insignificant. Were we to end the sample a year earlier (end-2004), the returns differential would be negative. In either case the differential is statistically indistinguishable from zero. The finding of no returns differential is surprising given the presumption in the literature of a substantial and positive returns differential for the United States. Our findings suggest that while it might be desirable for theoretical models to allow for returns differentials, the assumption of persistent differentials is on shaky footing.

How is it that we do not find a positive returns differential? Indeed, we find a positive composition effect, as all over the world equities had higher returns than bonds, U.S. claims are 
weighted toward equities, and U.S. liabilities are weighted toward debt. ${ }^{1}$ But the composition effect is offset by a negative return effect. U.S. equity markets performed very well over the past twelve years, while bond returns were more or less equal around the (developed) world, so in sum U.S. securities yielded higher returns than foreign securities. Given that the negative return effect almost exactly offsets the positive composition effect, it is surprising that we find any return differential (albeit one that is statistically insignificant). The explanation is that foreign countries, especially developed ones, have exhibited poor skill in shifting between bonds and equities within their U.S. portfolios. For example, foreigners tend to have a relatively high equity weight when U.S. equity prices have already peaked and a relatively low equity weight when U.S. equity prices are poised to rise. Thus, even though a positive composition effect exists, we do not find a statistically significant positive returns differential for the United States, and the U.S. returns differential would be even lower should foreigners exhibit more skill within their U.S. portfolios.

Our approach differs from previous analysis in at least two ways. First, we use information from actual bond and equity portfolios. Specifically, we utilize data on the country and asset class composition of U.S. portfolio claims and liabilities. By matching precise country and asset class weights to corresponding total market returns (and by being careful with the currency composition by asset class and country), we are able to obtain accurate estimates of the returns differential. Using data on bilateral positions also has the advantage of allowing us to distinguish differentials vis-à-vis developed from those vis-à-vis developing countries. ${ }^{2}$

The second way our study differs is methodological. Ascertaining the extent of the America's privileged status in having a positive returns differential vis-à-vis the rest of the world

\footnotetext{
${ }^{1}$ This structure of U.S. claims and liabilities is also noted by Gourinchas and Rey (2006a), Obstfeld and Rogoff (2005), and Lane and Milesi-Ferretti (2005b).

${ }^{2}$ It should be noted at the outset that by focusing on high quality data on bond and equity portfolios, we are necessarily excluding foreign direct investment (FDI), another important component of cross-border positions. There is a long-standing, positive returns differential for direct investment that most evidence suggests owes to some combination of a maturity effect (much of the FDI in the United States is relatively new, whereas U.S. direct investment abroad tends to have been placed a long time ago) and transfer pricing (Mataloni 2000, Hung and Mascaro 2004 and Higgins et. al. 2006). However, Gros (2006) and Heath (2007) argue that most of the differential on FDI owes to tax system effects, suggesting that for FDI any differential may be more apparent than real.
} 
is essentially an exercise in performance evaluation. Therefore, we utilize portfolio performance evaluation techniques inspired by Grinblatt and Titman (1993). Specifically, we decompose the return differential into its three components: composition, return, and timing effects. The first two-the composition and return effects-capture average characteristics of U.S. claims and liabilities. The composition effect would be positive were U.S. claims on foreigners weighted toward asset classes with higher average returns. The return effect would be positive were U.S. investors to earn higher average returns within each asset class. The third effect, timing, is driven by reallocations across different asset classes. The timing effect captures investment skill as given by the covariance between current weights and subsequent returns. A positive covariance between current asset weights-themselves the outcome of a buy-and-hold strategy or active trading - and subsequent asset returns would mean that portfolios were correctly positioned to capture subsequent returns. If portfolio weights and subsequent returns covary more positively in U.S. claims than in U.S. liabilities, U.S. investors display more skill abroad than foreign investors in the U.S. and the timing effect would be positive.

We perform many robustness checks. First, because our timing effect is a combination of active trading and the failure to reallocate after valuation changes alter the portfolio's composition, we differentiate between these two components. The more active component-the trading effect, a generally accepted metric of portfolio performance originated by Grinblatt and Titman (1993)—summarizes the ability of countries to shift their investments into asset classes that subsequently rise in value. We find that active trading plays an important role in the poor timing of foreign investors. Second, our results might have been driven by the accumulation of U.S. bonds by foreign officials, in particular the governments of emerging market countries. But our analysis confirms that they are not. Our results are actually much stronger for developed countries and carry through to private foreign investors. Finally, our sample period is long enough so that the overall effect of currency changes is negligible. Over our sample period, the dollar first appreciated and then depreciated; by the end it was roughly unchanged. Over shorter periods, 
currency movements will be the dominant force on returns differentials and, specifically, on the return effect (see, for example, Lane and Milesi-Ferretti (2005a) and Forbes $(2006,2007))$.

As an additional robustness check we compare our results to those obtained using publicly available data from the Bureau of Economic Analysis (BEA). We find that the calculated returns differential depends crucially on whether one uses original data releases or the current vintage of historical data available on BEA's website. This is because the extent of revisions differs for international investment positions (IIPs) and capital flows. While BEA fully adjusts positions data to reflect the findings of new benchmark surveys, an examination of the flow revisions reveals that BEA is only partially adjusting the flows data, perhaps because to incorporate into balance of payments revisions the flows must be attributed to a particular country and quarter. We show that the mismatch between the extent of revisions makes the U.S. returns differential appear greater than it actually is. Indeed, using the current vintage of historical data the returns differential appears large, but using the original data releases the returns differential is, as we find in our main analysis, essentially zero.

The paper proceeds as follows. In the next section we discuss the underlying data on international portfolios and returns characteristics. In Section 3 we decompose the returns differential into the composition, return, and timing effects. In Section 4 we show the difference between the returns differential calculated using the current vintage of BEA data and using the original BEA data releases. Section 5 concludes.

\section{Returns Differentials from Actual Portfolios}

In this section we describe the bilateral positions and returns data and then calculate the returns differentials. To compute returns differentials, we use monthly data on bilateral international portfolio positions in bonds and equities. The bilateral aspect is important in enabling us to differentiate between different types of foreign countries. For example, portfolio 
considerations of emerging market countries might be very different from those of developed countries.

\subsection{Positions}

We use the highest quality data set available on the portfolio debt and equity investment positions of U.S. investors abroad and foreign investors in the United States. This data was designed in Thomas, Warnock, and Wongswan (2006), used in Warnock and Warnock (2006), and refined in Bertaut and Tryon (2007). Monthly bilateral investment positions are constructed using two components of data reported by the Treasury International Capital Reporting System (TIC): infrequent but highly accurate benchmark surveys of holdings (both foreign holdings of U.S. securities and U.S. holdings of foreign securities) and net monthly transactions (both net purchases of U.S. assets by foreigners and net purchases of foreign assets by U.S. residents). The technique to construct the monthly positions data is detailed in Appendix A. The end result is high-quality estimates of monthly positions of foreigners in U.S. securities (“U.S. liabilities") and U.S. positions in foreign securities (“U.S. claims").

Our data cover portfolio investment in long-term securities, specifically debt instruments with greater-than-one-year original maturity ("bonds") and equities. ${ }^{3}$ While the TIC system includes most countries of the world, we include only those countries for which we have at least fifty monthly observations on both equity and bond returns between January 1994 and December 2005. This leaves us with nineteen developed countries and nineteen emerging markets. These countries account for the majority of U.S. portfolio investment abroad as well as the majority of foreign investment in the United States. ${ }^{4}$

\footnotetext{
${ }^{3}$ We exclude bank lending, which would not affect our analysis because short-term deposits earn, if anything, near zero returns and cross-border holdings of short-term securities are very small at less than 20 percent the size of holdings of long-term debt (Treasury et al. 2006a, 2006b).

${ }^{4}$ In 2004, the countries in our sample account for 84 percent and 80 percent of U.S. equity and bond investment abroad and 77 percent and 73 percent of all foreigners' equity and bond investment in the United States. Of the international investment that we do not cover, Caribbean financial centers account for more than half.
} 
One limitation is that the TIC data distinguish between private and official positions only at the aggregate level. Therefore, our country-level analysis groups together official and private flows. We recognize that foreign official purchases of U.S. assets may be for reasons other than mean-variance optimization. With the exception of Japan, private positions dwarf official holdings in developed countries, but for emerging market countries official positions are likely to be more important. In robustness checks we delve further into this issue.

\subsection{Returns}

We select the returns series that most closely correspond to actual international holdings. For U.S. securities, for returns on U.S. bonds we use the weighted average of Lehman Brothers U.S. Treasury, corporate and agency bond indices, with the weights being foreigners' positions in each respective bond type. Foreign investors, especially those from emerging markets, tend to overweight Treasury and Agency bonds relative to a market-capitalization benchmark such as the Lehman Brothers Aggregate U.S. bond index, so it is important to use the actual weights of foreign investors in the three types of bonds to produce an accurate measure of their returns on U.S. bonds. For returns on U.S. equities we use the return on the gross MSCI U.S. index. The index is market capitalization weighted and, with roughly 300 large and liquid U.S. firms, is comparable to the S\&P 500 (which unfortunately includes some foreign firms).

For foreign securities, for returns on foreign equities we use dollar returns on the gross MSCI equity index for each country. MSCI indexes are appropriate because MSCI firms represent almost 80 percent of U.S. investors' foreign equity investment (Ammer et al. 2006). For foreign bonds, to a large extent U.S. investors tend to hold local currency bonds in developed countries and dollar-denominated bonds in emerging markets (Burger and Warnock, 2007). Thus, for developing countries we use J.P. Morgan's EMBI+ indices (which are comprised of dollardenominated bonds). In those developed countries where U.S. holdings of local currency bonds are predominant, we use the MSCI bond index (which is an index of local-currency-denominated bonds). In those developed countries where U.S. holdings of dollar-denominated bonds are 
significant we calculate returns as the weighted average of the MSCI bond index and MSCI Eurodollar Credit index (which is an index of dollar-denominated bonds), with the weights on the Eurodollar index being the shares of dollar denominated bonds in U.S. holdings of foreign bonds. ${ }^{5}$ When calculating returns on the aggregate foreign bond and foreign equities portfolios, we weight each country according to U.S. bond (or equity) holdings in that country. The average weight of each country in U.S. foreign equity and bond portfolios and the average returns on each country's equities and bonds appear in Table I.

Our sample period covers the 144 months between January 1994 and December 2005. The starting point is determined by the availability of MSCI bond indices, which begin in December 1993. The ending point is determined by the availability of U.S. foreign asset positions, which are available through December 2005. For some countries, equity or bond returns data begin after January 1994. We add these countries to the U.S. asset and liability portfolios when the data for both equity and bond returns become available (see the last column in Table I). Countries added after January 1994 tend to have very low weights in both U.S. claims and liabilities portfolios, so our results are nearly identical if we restrict our study to countries with returns data for the entire sample period.

\subsection{Characteristics of U.S. foreign claims and liabilities}

Table II shows the descriptive statistics for aggregate equity weights in U.S. claims and liabilities and aggregate returns on U.S. and foreign bonds and equities. It is evident from Panels A and B that U.S. claims (that is, U.S. investors' foreign portfolios) are weighted heavily toward equities, while U.S. liabilities (foreigners' portfolios in the U.S.) are weighted toward bonds. This resembles the "venture capitalist" capital structure of the U.S. external balance sheet as pointed out by Gourinchas and Rey (2006a). Specifically, the equity-to-bond ratio in U.S. claims is 71:29 across all countries, with equities having a higher weight in U.S. investors' developed country

\footnotetext{
${ }^{5}$ The developed countries where U.S. holdings of dollar denominated bonds are significant include Australia, Belgium, Canada, Finland, France, Germany, Ireland, Netherlands, Sweden and the United Kingdom.
} 
portfolios (72:28 equity-to-bond ratio) than in the emerging market portfolios (60:40). By contrast, the equity-to-bond ratio in U.S. liabilities is $42: 58$, roughly that (46:54) for developed countries' positions, but much lower for emerging markets' portfolios (9:91).

Returns are shown in Panels C and D. Note at the outset that, while over short periods returns differentials between claims and liabilities are driven primarily by movements in the exchange value of the dollar, over our 12-year sample the dollar was essentially flat. For example, for the short period from end-2001 to end-2004 the dollar depreciated 10 percent per year against the currencies of developed countries (that is, the Fed's Major Currencies Index fell 10 percent per year), but from January 1994 to September 2003 it was flat, and over our whole sample it depreciated only 4.7 basis points per month, or 0.56 percent per year. Thus, for our sample the effect on the returns differentials of exchange rate movements is very minor, whereas their effect in shorter samples can be sizeable.

Panel C shows that over the period from 1994 through 2005 data on actual portfolios indicate that returns were higher on U.S. equities (0.94 percent per month) than on foreign equities ( 0.77 percent overall, with 0.80 in developed countries and 0.85 in emerging markets). For bonds (Panel D), returns on developed country bonds ( 0.57 percent per month) were somewhat higher than returns on U.S. bonds (0.48), while returns on emerging market bonds were much lower (0.20). Overall, there is no evidence in Panels C and D that U.S. claims have substantially higher returns than U.S. liabilities. If we consider all countries, foreign bonds provided slightly higher returns than U.S. bonds (about 18 basis points per year), but returns on U.S. equities were substantially higher (about 209 basis points per year) than returns on foreign equities. No return discount or premium is obvious within asset classes; to a first approximation, the securities returns in the major markets are similar.

Our finding that the United States does not earn substantially higher returns within each asset class contrasts with that of Gourinchas and Rey (2006a). In particular, compared to our returns they report substantially higher returns on U.S. equity claims and substantially lower 
returns on U.S. debt liabilities. In addition to different time periods-we compare our 1994-2005 results to their 1973-2004 calculations-there are at least two other reasons for the differences. First, in calculating returns on U.S. equity claims, we use country weights that change monthly, while Gourinchas and Rey appear to use fixed weights. Specifically, when calculating returns on U.S. equity claims, Gourinchas and Rey use constant country weights as of 1997, although country weights in U.S. investors' equity portfolios can change dramatically over time (Kho, Stulz, and Warnock 2006; Thomas et al. 2006). Moreover, applying 1997 weights to the entire 1973-2004 period will naturally overstate returns, as all else equal 1997 weights will tend to be high in countries that experienced high returns prior to 1997. Second, in calculating returns on U.S. debt liabilities we take into account their composition into treasury, agency and corporate bonds. Gourinchas and Rey use returns on U.S. short-term and long-term treasury securities as the return on U.S. debt liabilities. Since higher yielding corporate bonds make up as much as $42 \%$ of U.S. long-term debt liabilities (see Table 1 in Treasury et al., 2006a), this may understate returns on U.S. debt liabilities. ${ }^{6}$

\subsection{Actual and Hypothetical Portfolio Returns}

The returns data in Table II, together with the portfolio weights, suggest that U.S. investors should not have earned a much higher return on their foreign portfolios than foreigners earned on their U.S. portfolios. Indeed, if the average portfolio weights were maintained throughout the period, the returns differential (of U.S. claims over U.S. liabilities) would be roughly zero. This is shown in the column labeled "Hypothetical" in Table III. The hypothetical returns are calculated by multiplying average weights and average returns and summing across asset classes. This calculation shows that if the average weights were maintained throughout the

\footnotetext{
${ }^{6}$ There are other differences in the calculation of returns on U.S. equity assets. For example, we use information on 39 countries, whereas Gourinchas and Rey use only 12. Also, we use MSCI indices which tend to include the large firms that international investors tend to hold, whereas they use local market indices that tend to be broader than the MSCI.
} 
period, the returns differential would be 0.015 percent per month vis-à-vis all countries, 0.041 percent vis-à-vis developed countries, and 0.095 percent vis-à-vis emerging markets.

In reality, actual portfolio returns (shown in the column labeled "Actual") behaved quite differently. Whereas the returns of emerging market investors on their U.S. positions were roughly equal to the hypothetical returns, investors from developed countries earned far less than the hypothetical returns. This sub-par performance by developed countries resulted in a slightly positive returns differential in favor of U.S. claims. Overall, for all countries the returns differential is positive but essentially zero ( 0.056 percent per month, essentially the amount of monthly dollar depreciation over our sample). Vis-à-vis emerging markets, the returns differential is substantially more positive at 0.110 percent per month, or 1.32 percent per year. In no case is the differential statistically distinguishable from zero, in part because of the volatility of asset prices and exchange rates.

One implication of these calculations is clear. Over the period from 1994 to 2005-a period of increasing financial globalization-there is no evidence that U.S. portfolio claims provided substantially higher returns than U.S. portfolio liabilities. A positive returns differential, and the stabilizing influence that it would lend to the global economic system absent a sustained dollar depreciation, is not apparent when one examines actual bond and equity portfolios.

Table III does leave one question unanswered: Why do the U.S. portfolios of investors from developed countries perform so much worse than their average portfolio weights would suggest? Specifically, why do developed countries' actual portfolios return 0.043 percent per month (52 basis points per year) less than the hypothetical returns? The answer is that any difference between the hypothetical and actual returns must be attributed to the relationship between the timing of changes in portfolio weights and subsequent returns. If actual returns are lower than hypothetical returns, portfolio weights must covary negatively with subsequent returns. This suggests that timing may be an important component of the return differential (or lack thereof) between U.S. claims and liabilities. Therefore, in the next section we formally 
decompose the returns differentials into components that depend on average weights and average returns (composition and return effects) and components that depend on portfolio timing (foreign and U.S. timing effects).

\section{Returns Decomposition}

To further understand our result of no returns discount for U.S. liabilities relative to U.S. claims, we decompose the returns differentials into three component effects: composition, return, and timing.

\subsection{Methodology}

The average return on any portfolio $p$ can be written as the time series average of the sum of the products of lagged asset weights and returns:

$$
\bar{r}^{p}=\frac{1}{T} \sum_{t=1}^{T} \sum_{j=1}^{N} w_{j, t-1}^{p} r_{j, t}^{p}
$$

where $w_{j, t-1}^{p}$ is portfolio weight of asset $j$ at the end of period $t-1$ (the beginning of period $\left.t\right), r_{j, t}^{p}$ is the period $t$ return on asset $j$ in portfolio $p$, and $N$ is the number of assets in the portfolio. Note that equation (1) can be also written as:

$$
\bar{r}^{p}=\sum_{j=1}^{N} \bar{w}_{j}^{p} \bar{r}_{j}^{p}+\frac{1}{T} \sum_{t=1}^{T} \sum_{j=1}^{N}\left(w_{j, t-1}^{p}-\bar{w}_{j}^{p}\right) r_{j, t}^{p}
$$

where $\bar{w}_{j}^{p}$ and $\bar{r}_{j}^{p}$ are the time-series averages of the weights and returns on asset $j$. Equation (2) shows that the average portfolio return depends on two components: (1) average returns and average holdings, and (2) the covariance of portfolio weights with subsequent returns. For investors whose portfolio weights and future returns move together, these covariances will tend to be positive. Note that if either returns or weights remain constant, the second term in (2) is zero and portfolio return will depend only on average weights and average returns. If, as is more likely, investors change their portfolio weights and returns are not constant, the second term is potentially important. 
Using equation (2) to express the average return on U.S. claims, $\bar{r}^{c}$, and liabilities, $\bar{r}^{l}$, the returns differential can be written as:

$$
\begin{aligned}
\bar{r}^{c}-\bar{r}^{l} & =\sum_{j=1}^{N} \frac{\left(\bar{r}_{j}^{c}+\bar{r}_{j}^{l}\right)}{2}\left(\bar{w}_{j}^{c}-\bar{w}_{j}^{l}\right) \\
& +\sum_{j=1}^{N} \frac{\left(\bar{w}_{j}^{c}+\bar{w}_{j}^{l}\right)}{2}\left(\bar{r}_{j}^{c}-\bar{r}_{j}^{l}\right) \\
& +\frac{1}{T} \sum_{t=1}^{T} \sum_{j=1}^{N}\left(w_{j, t-1}^{c}-\bar{w}_{j}^{c}\right) r_{j, t}^{c} \\
& -\frac{1}{T} \sum_{t=1}^{T} \sum_{j=1}^{N}\left(w_{j, t-1}^{l}-\bar{w}_{j}^{l}\right) r_{j, t}^{l}
\end{aligned}
$$

Each line in equation (3) represents a component of the decomposition of the difference between the returns on U.S. claims and liabilities. The first line, the composition effect, is the weighted sum of the differences between the average weights of each asset class in U.S. claims and liabilities. The weight for each asset class is the average return of the asset class in claims and liabilities. If both U.S. and foreign investors put the same average weight on each asset class, the composition effect is zero. Should U.S. investors put a higher weight on higher yielding asset classes, the composition effect would be positive.

The second line, the return effect, is the weighted sum of the differences between returns on U.S. claims and liabilities within each asset class. The weight for each asset class is the average weight of the asset class in claims and liabilities. If each asset class has the same average return in both claims and liabilities, the return effect is zero. If average returns in each asset class tend to be higher for U.S. claims than for U.S. liabilities, the return effect will be positive.

The timing of U.S. investors abroad is captured by the third line, while the fourth captures the timing of foreign investors in the United States. Both lines are the sum of sample covariances between investors' weights on each asset class and subsequent returns on that asset 
class. This is a version of Grinblatt and Titman's (1993) measure of portfolio performance. ${ }^{7}$ If U.S. investors put relatively high weights on assets that have subsequent high returns, these covariances will be positive and will contribute positively to the aggregate return differential between U.S. claims and liabilities. In contrast, positive covariances between foreign investors' weights and subsequent returns will contribute negatively to the aggregate return differential: The better the timing of foreign investors in the United States, the lower the return on U.S. claims relative to U.S. liabilities. Therefore, foreign timing enters equation (3) with a negative sign.

The timing effects can be further broken down into the portion driven by returns on existing positions and the portion driven by trading. We separate the two by constructing buyand-hold weights for each asset. The weight of asset $j$ at the end of $t-1$ that would have resulted from a buy-and-hold strategy adopted $k$ periods ago can be calculated as follows:

$$
w_{j, t-1, k}^{b h}=w_{j, t-1-k} \prod_{\tau=t-k}^{t-1}\left(1+r_{j, \tau}\right) /\left(1+r_{p, \tau}^{b h}\right)
$$

where $w_{j, t-1-k}$ is the actual weight at the end of $t-1-k$. This weight is then updated according to actual returns on asset $j$ and returns on a buy-and-hold portfolio $r_{p}^{b h} \cdot{ }^{8}$ With this we can decompose the timing effect into the part that depends on the deviations of actual weights from buy-and-hold weights and the part that depends on the deviation of actual weights from average weights:

\footnotetext{
${ }^{7}$ In general, the Grinblatt and Titman (1993) measure can be written as $\frac{1}{T} \sum_{t} \sum_{j}\left(w_{j, t-1}-E\left[w_{j, t-1}\right]\right) r_{j, t}$ where $\mathrm{E}\left(\mathrm{w}_{\mathrm{j}, \mathrm{t}-1}\right)$ is the expected weight on asset $\mathrm{j}$ at $\mathrm{t}-1$ that needs to be estimated. As discussed in Wermers (2006) there are many approaches to estimating this expected weight. One possibility is to use the timeseries average weight as an estimate of the expected weight. Our timing effect uses this approach. Another possibility, suggested by Ferson and Khang (2003), is to use buy-and-hold weights as an estimate of expected weights. Our trading effect, discussed below, uses the buy-and-hold weight as an estimate of the expected weight.

${ }^{8}$ In order to construct the buy-and-hold weight at the end of $\mathrm{t}-1$, we need the return on a buy-and-hold portfolio in period $\mathrm{t}-1$. This is not circular because the buy-and-hold portfolio return in $\mathrm{t}-1$ uses buy-andhold weights from $\mathrm{t}-2$.
} 


$$
\frac{1}{T} \sum_{t=1}^{T} \sum_{j=1}^{N}\left(w_{j, t-1}-\bar{w}_{j}\right) r_{j, t}=\frac{1}{T} \sum_{t=1}^{T} \sum_{j=1}^{N}\left(w_{j, t-1}-w_{j, t-1, k}^{b h}\right) r_{j, t}+\frac{1}{T} \sum_{t=1}^{T} \sum_{j=1}^{N}\left(w_{j, t-1, k}^{b h}-\bar{w}_{j}\right) r_{j, t}
$$

We call the first term on the right hand side the trading effect. It measures the covariance between the deviations of actual weights from buy-and-hold weights and subsequent returns. If investors tend to increase weights in assets that subsequently rise in value, this term will be positive. We calculate this for both U.S. investors abroad and foreign investors in the United States. We call the second term the passive effect. It measures the covariance between the deviations of buy-andhold weights from average weights and subsequent returns. This covariance will tend to be positive if returns are positively serially correlated.

\subsection{Return, Composition and Timing Effects}

In Table IV we decompose the difference between the return on U.S. claims and liabilities into the composition, return, and timing effects. The composition effect is always positive because U.S. claims are on average weighted toward stocks, which have high average returns. The composition effect is considerably larger vis-à-vis developing countries (about 3.5 percent per year) than vis-à-vis developed countries (about 1.1 percent per year). In both cases, however, the composition effect is statistically insignificant. ${ }^{9}$

The return effect is negative. This indicates that within asset classes, U.S. claims tend to have lower returns than U.S. liabilities. While U.S. investors earn slightly more on foreign bonds than foreigners earn on U.S. bonds, U.S. investors earn much less on foreign equity. The differences in returns within each asset class partially offset each other. However, since equities

\footnotetext{
${ }^{9}$ Because the composition effect is a product of two averages, its distribution is unknown. In order to assess statistical significance of the composition effect, we calculate its standard error using bootstrapping. We obtain 1000 different samples by drawing 144 observations from our data with replacement 1000 times. Using these samples we calculate 1000 compositions effects. The standard error of our original composition effect is the standard error of these 1000 composition effects. The $\mathrm{z}$-statistic reported in the table is the original composition effect divided by the bootstrapped standard error.
} 
have on average a higher weight, the return effect is negative. The return effect is even more negative with respect to developing countries. This is driven by the poor performance of assets (especially bonds) in developing countries during our sample period.

The last two columns in Table IV show the foreign and U.S. timing effects, that is, the sums of covariances between asset weights and subsequent returns. Using all countries we see that the foreign timing effect is negative and statistically significant. This means that foreign investors have relatively high weights on assets that subsequently have low returns. The magnitude of the effect is about 0.06 percentage points per month. Thus, poor timing by foreign investors reduces their U.S. return by 70 basis points per year and positively contributes to the returns differential. In fact, negative foreign timing is the only statistically significant term in the decomposition of the return differential between U.S. claims and liabilities. The U.S. timing effect is also negative, but is considerably smaller and statistically insignificant.

The significantly negative timing effect for foreign investors could owe to the mechanical accumulation of dollar reserves. For example, foreign governments could, for various reasons, accumulate U.S. bonds just before U.S. bonds underperform. To verify that the poor timing of foreign investors is not driven by dollar reserve accumulation, we re-estimate our decomposition using aggregate private positions in the United States (Panel B). Even when we consider only private investment, foreign timing is negative and statistically significant. Because the split between foreign private investors and foreign governments is murky in the TIC data (Warnock and Warnock, 2006) and because with the exception of Japan official purchases are likely negligible for developed countries, we also split between developed and developing countries (Panels $\mathrm{C}$ and $\mathrm{D}$ ). The foreign timing is significant and negative for developed countries, again suggesting that the poor timing of foreign purchases of U.S. securities is not driven by mechanical accumulation of dollar reserves by emerging markets. Indeed, for developing countries foreign timing is statistically insignificant. We re-estimated Panel C without Japan, without the United Kingdom (since some developing countries may trade through London), and 
without both Japan and the United Kingdom, and we found nearly identical (unreported) results in all cases: For developed countries, foreign timing is negative and statistically significant.

\subsection{Timing due to trading vs. revaluation of existing positions}

The variation in weights on different asset classes is to some extent driven by returns on existing positions. For example, when equities do particularly well and investors do not rebalance their portfolio, the equity weight will rise. The sample period that we consider is characterized by the worldwide boom in equities that ended in 2000 and re-emerged in 2003. This is shown in Figures 1 and 2. The top panel in each figure shows year-over-year returns in equities and bonds; in both the United States (Figure 1) and abroad (Figure 2), equity returns were generally higher than bond returns from the beginning of the sample until 2000, and again from 2003 to the end of the sample. The bottom panels of the two figures show equity weights from actual portfolios (the thick lines) and theoretical 24-month buy-and-hold equity weights (thin lines). ${ }^{10}$ A relationship clearly holds between relative performance for equities and the actual weight on equities; while equities were outperforming bonds, investors (both U.S. and foreign) allowed their portfolios to be more heavily weighted in equities. Neither foreign nor U.S. investors seem to rebalance their portfolio when returns change the portfolio weights of asset classes.

In order to distinguish between timing that is a result of a passive strategy versus deliberate trading, we decompose the timing effect into trading and passive effects. As described in Section 3.1 the trading effect is the covariance between the deviations of actual weights from buy-and-hold weights and subsequent returns. Table V shows the foreign and U.S. trading effects as well as the passive effects. Both trading and passive effects are calculated for different lags corresponding to different buy-and-hold weights. For example, lag 6 uses buy-and-hold weights that would have resulted from a buy-and-hold strategy adopted six months ago.

\footnotetext{
${ }^{10}$ The buy-and-hold equity weight series begins only in January 1996 since it is the weight that foreigners would have in equity had they not traded for twenty-four months starting in January 1994.
} 
Panel A shows the results using all countries. The foreign trading effect is always negative and statistically significant. The passive strategy effect is also always negative and sometimes significant. This indicates that the negative foreign timing effect that we documented in Table IV is due to poor passive strategy but mostly to ill-timed trading. Foreign investors make new purchases (sales) that tend to be followed buy low (high) returns. Interestingly, the foreign trading effect is negative and significant for both developed and developing countries. Even though the overall timing effect in Table IV was statistically significant only for developed countries, the part of the timing effect that results from active trading is negative and significant in both developed and developing countries. To the extent that we can interpret the negative trading effects as a lack of investment skill, it appears to be low for investors from both developed and developing counties. The magnitude of the effect is about 3 basis points per month at the 12-month lag and 6 basis points at the 24-month lag. This translates to roughly 36 and 72 basis points per year. In contrast, the U.S. trading effect is almost always positive although never statistically significant. ${ }^{11}$

Poor timing on the part of foreign investors is apparent in Figure 1. For example, in the twenty-four months after January 1994 U.S. equities outperformed U.S. bonds, so the buy-andhold weight for January 1996 is considerably higher than the actual weight from January 1994 and the actual weight for January 1996. In fact, actual equity weights are lower than the buy-andhold weights for most of the second half of the 1990s. Putting a relatively low weight on U.S. equity during the late 1990 s turned out to have been a poor decision, as U.S. equities performed spectacularly during this period. When U.S. equities peaked in early 2000, foreigners' actual equity weights are higher than the buy-and-hold weights, indicating that foreign investors were buying stocks (or selling bonds) —in hindsight a poor decision. We see similarly poor timing toward the end of the sample. During 2003 and 2004, foreign investors' weight in U.S. equity

\footnotetext{
11 This is entirely consistent with Thomas et al. (2006), who found that U.S. investors beat foreign benchmarks not by skilled month-to-month trading but as a result of longer standing differences from benchmark allocations.
} 
remains relatively low despite the strong performance of the U.S. stock market. Had foreign investors allowed their equity positions to appreciate in 2003, their equity weight (and the return on their portfolio) would have been higher in 2004. Instead, foreign investors sold U.S. equities or bought U.S. bonds when equities were about to outperform bonds. ${ }^{12}$

Figure 2 allows a similar analysis for U.S. claims. In the late 1990s U.S. investors' buyand-hold weight is mostly lower than the actual equity weight. Therefore, U.S. investors deliberately shifted toward equity while equity returns were relatively high. U.S. investors continued to shift toward foreign equities even as foreign equities were falling between 2000 and 2002. However, unlike foreign investors in the United States, U.S. investors abroad appear to have deliberately shifted into equities before the 2003 and 2004 recovery in global equity markets. As the insignificant coefficients on the U.S. trading effect in Table V show, in a statistical sense U.S. timing is neither poor nor exceptional.

In Table VI we calculate the trading and passive effects for the aggregate private positions in the United States. We find that foreign private positions also exhibit a negative and statistically significant trading effect. This means that private foreign investors tend to buy (sell) assets that subsequently experience low (high) returns. This is further evidence that our aggregate results are not driven by mechanical accumulation of dollar reserves but appear rather to be driven by the behavior of private investors.

\subsection{Decomposition over 1994-1999 and 2000-2005 subsamples}

In this subsection we investigate whether the decomposition of the return differential varies over time. Our aim is to determine which components of the return differential are stable over time and which vary. In part, this is motivated by the need to understand the permanency or transitory nature of the return differential (or lack of thereof). In Table VII we split our sample into two periods: January 1994 through December 1999, and January 2000 through December

\footnotetext{
${ }^{12}$ Poor timing of foreign investors is consistent with the findings of Choe et al. (2005) for foreign investors in Korea.
} 
2005. The table shows that the composition and return effects switch signs between the two periods. For the return effect, from 1994 through 1999 U.S. equities and bonds outperformed their foreign counterparts, so the return effect is negative (that is, within each asset class foreign investors earned more in the United States than U.S. investors earned abroad). The return effect becomes positive during the period from 2000 through 2005, when both U.S. equities and U.S. bonds performed worse than their foreign counterparts. As regards the composition effect, from 1994 to 1999 it is positive; U.S. claims are weighted more heavily toward equities than U.S. liabilities are and during this period equities outperformed bonds. But between 2000 and 2005 both U.S. and foreign equities performed far worse than bonds, so the composition effect becomes negative. Neither the composition effect nor the return effect appears to be a permanent feature of U.S. external positions. ${ }^{13}$

The transitory nature of composition and return effects is driven by volatile returns. With volatile returns, timing of reallocations becomes more important. Table VII shows that the foreign timing effect is negative during both time periods but is statistically significant only in the 2000 to 2005 subperiod. As in the full sample, U.S. timing remains statistically insignificant during both time periods. In Table VIII we decompose the timing effect into the trading and passive effects. We see that at the 12- and 24-month horizons the foreign trading effect is consistently negative and statistically significant in both sub-samples. The magnitude of the trading effect is roughly the same in the two sub-samples as in the full sample. Therefore, poor timing of new sales and purchases by foreign investors in the United States seems rather persistent. It is worth emphasizing that the number of observations in the two sub-samples is relatively low. Given this relatively small number of observations, the significance and the robustness of the negative trading effect of foreign investors in the United States is striking. It

\footnotetext{
${ }^{13}$ Of course, to the extent that over very long periods of time equities outperform bonds, we would expect the composition effect to be positive.
} 
suggests that the poor timing found using the full sample represents a genuine difference in investment style rather than bad luck on the part of foreign investors.

\section{Why the Presumption of a Positive Returns Differential?}

A question raised by our analysis is why there is a presumption that the U.S. has a positive returns differential. One reason, as noted in the introduction, is that overall data for the United States also includes foreign direct investment; there is long-standing evidence of a positive returns differential for direct investment, although some recent papers call this into question (Gros 2006, Heath 2007). But aside from foreign direct investment, there is still the presumption of a U.S. earning advantage within each asset class. Why?

There are essentially two ways to compute total returns from publicly available data. One involves gathering detailed information from each year's U.S. international investment position (IIP) presentation; we will refer to this as the IIP method. The other is much easier, as it entails downloading from BEA's web site the current vintage of historical data on the U.S. international investment position (IIP) and international capital flows. Because IIP data are always fully revised to reflect the findings of benchmark surveys, but international capital flows data are only partially revised, the latter imparts a bias that makes the U.S. returns differential appear much greater than it actually is. We call this latter method Partially Revised, because an important aspect is that flows data are only partially revised. Details on the data underlying each method are provided in Appendix B.

\subsection{IIP Method}

In general, total returns arise from both capital gains and income streams (e.g., coupon payments on bonds and dividend streams from equities). To compute the dollar value of capital gains using IIP data, note first that since 1983 Table 1 of each year's annual IIP presentation decomposes the change in year-end positions into the contributions from net flows, valuation adjustments due to price and exchange-rate changes, and "other changes". For portfolio positions 
in bonds and equities, "other changes" typically owe to changes in coverage or methodology, and hence for our purposes should not be counted as valuation changes. Thus, from each annual IIP presentation the dollar value of valuation changes are those that are from price and exchange rate changes. For income streams, we gather the U.S. equity and debt income series (payments and receipts) provided by BEA to the IMF. These data have been reported since 1986 . To compute total returns, we divide the sum of capital gains and income streams by the position at the end of the preceding year plus, because flows early in the year will add to valuation changes later in the year, half of the year's flows.

\subsection{Partially Revised Method}

The Partially Revised (PR) method differs from the IIP method in the calculation of capital gains. The revised position estimates by product for 1976-2005 are available in Table 2 of the International Investment Position area of the BEA website (www.bea.gov/international). The revised flow estimates for 1982-2005 are available from the Balance of Payments area of the same website. Capital gains can be estimated as the change in the year-end position less new flows and, as in the IIP method, omitting valuation adjustments due to "other changes". A problem with the revised position estimates is that they contain series breaks that arise from changes in coverage and other factors; some of these breaks are reported as other changes in each annual IIP, so we subtract these other changes from the capital gains.

As in the IIP method, to calculate total returns we add the same income streams (that BEA reports to the IMF) and, to estimate total returns, we divide by the sum of the revised position at the start of the year plus half of the year's revised flows.

\subsection{A Comparison of Methodologies}

Figures 3 and 4 show total returns from the IIP and PR methods as well as our estimates (labeled CDW). The start date is governed by the availability of data on income streams, which begins in 1986. The underlying data for our estimates begin in 1994. 
The top panel of Figure 3 shows that total returns on U.S. holdings of foreign bonds using the PR method are almost always greater than returns computed using the IIP method or our method. The same holds true for U.S. holdings of foreign equities until about 1998 (bottom panel). Returns data on foreign holdings of U.S. securities are less problematic (Figure 4). For bonds, returns computed using the PR method are high in the late 1980s, but somewhat lower than the others starting in 1996. For equities, the differences between the three methods are small.

Table IX shows the impact of these differences on the returns differential. For the 19862005 period (Panel A), the PR method produces returns on U.S. claims that are far greater than those computed using the IIP method. Foreigners' returns on U.S. liabilities are comparable in the two methods, so on net the returns differential is much higher using the PR method ( 8 percent vs. 1.4 percent). Panel B shows estimates for our sample period, 1994-2005; total returns using our data are quite similar to those using the IIP method and the main conclusion from Panel A holds. As was the case in the earlier sample, the PR method makes it appear that U.S. investors earn substantially more on their foreign portfolios than foreigners earn on their U.S. portfolios. ${ }^{14}$

The main reason for the discrepancy between estimates computed using the PR and IIP methods is that the PR method is impacted by a disconnect in the revisions policies for data on positions and capital flows. Positions data are typically fully revised to reflect new data from the high quality but infrequent benchmark surveys. In contrast an examination of BEA's flow revisions reveals that flows data are only partially revised, perhaps in part because to incorporate into the balance of payments presentation revision to flows must be attributed to a particular country and quarter.

Differential revisions policies need not result in a positive returns differential, but systematic aspects of the revisions do indeed produce such a result. First, note that for positions

\footnotetext{
${ }^{14}$ As noted in Appendix B, capital gains computed using the PR method exclude valuation adjustments due to other changes reported on each annual IIP. Were we to include other changes there would be only minor differences in the total returns. For example, for the 1994-2005 period the equity liability total return increases to 14.1 percent, the bond liability total return decreases to 2.9 percent, and the differential increases to 5.0 percent.
} 
the revisions in both claims and liabilities tend to be positive due to constantly expanding coverage. Given that flows are only partially revised, such upward revisions would automatically result in high returns (for both claims and liabilities) using the PR method. But on the liabilities side, working against this general tendency of upward revisions are two things: (i) revisions to U.S. liabilities, tend to be minor because BEA has better information on foreign holdings of U.S. securities (especially for Treasury bonds), and (ii) any upward revisions to U.S. bond liabilities are partially offset by downward revisions associated with repayments on asset-backed securities that are not captured in the flow data. Therefore, the PR method will naturally produce a greater returns differential as it tends to overstate capital gains on U.S. assets (because higher positions without corresponding revisions to flows imply higher capital gains) but less so on U.S. liabilities. In contrast, original IIP releases contain data on flows and positions that correspond to each other and hence offer a more accurate estimate of capital gains and total returns. Table IX shows that when using the original IIP data - or our data on actual portfolios-the returns differential disappears. ${ }^{15}$

\section{Conclusion}

Our original goal in this paper was to improve our understanding of the positive returns differential that the United States is privileged to receive on its net international positions. However, over 1994-2005, a period of rapid financial globalization, we do not find a statistically significant difference between the returns on U.S. portfolio claims and liabilities. While U.S. portfolio claims are weighted more heavily toward equity than are U.S. liabilities, and equities have higher average returns than bonds, the effect of this "venture capitalist" structure of U.S. external positions was neutralized by the superior performance of the U.S. equity market relative to foreign equity markets. Moreover, the returns that foreigners achieved in the United States

\footnotetext{
${ }^{15}$ Note that our estimates in Table IX are based on averages, so they do not include timing effects and are thus comparable to our Hypothetical returns in Table III.
} 
would have been even higher if not for their poor timing in reallocating between stocks and bonds. We find that poor timing lowered foreigners' return in the United States by 70 basis points per year.

Our results have implications for current global imbalances. Our finding of no return differential between U.S. claims and liabilities means that one stabilizing aspect of the current international economic system is on shaky footing. In theoretical models, relative to the presumption of a positive returns differential, a zero returns differential would increase the likelihood of a disorderly adjustment in the U.S. current account and the dollar. While we find no evidence of superior market timing ability by U.S. investors abroad, they do quite well relative to foreign investors in the United States.

Understanding why foreign investors consistently fail to anticipate shifts in relative returns on different asset classes is an important question for future research. One possibility is that foreign investors in the United States chase returns as suggested in Bohn and Tesar (1996). Superior U.S. investment skill is also consistent with the evidence in Thomas et al. (2006), who find that U.S. investors' foreign equity portfolio outperforms capitalization-weighted benchmarks. It is also possible that U.S. returns are less predictable than foreign returns, which would be consistent with studies that find negative market timing among U.S. mutual funds (see, for example, Ferson and Schadt 1996). Concerning current global imbalances, we need to know whether poor foreign timing is permanent or transitory. Should foreign investors improve their timing, the U.S. external position would worsen at a faster pace. Our estimate of poor foreign timing is stable over our 12-year sample, but we have no confidence in its permanency. Increasing financial integration, cross ownership of financial institutions, as well as improving information flows suggest that any skill advantage is unlikely to persist. ${ }^{16}$

\footnotetext{
${ }^{16}$ For example, Dvorak (2005) finds that in Indonesia, U.S.-based global brokerages improve the investment performance of both local and foreign investors.
} 
Another area for future research is foreign investors' reallocations within each asset class. Currently, we are assuming that foreigners invest in market indices for both equity and bonds, that is, we assume that foreign investors' allocation within each asset class matches that of the benchmark index for each asset class. This assumption is on solid footing, as security-level analysis of holdings suggests that at a point in time the bulk of cross-border holdings is in just those securities that are in benchmark indices. But if over time foreign investors' poor timing within asset classes is as poor as is their timing between asset classes, then we underestimate the true magnitude of the timing and trading effects. 


\section{Appendix A. Position Estimates}

To estimate cross-border securities positions, one can utilize the method developed in Thomas et al. (2006) and refined in Bertaut and Tryon (2007). ${ }^{17}$ This appendix provides a summary of the methodology and necessary data.

\section{A.1 Data}

Data on cross-border portfolio holdings of securities and monthly transactions are collected as part of the TIC system, available at http://www.treas.gov/tic. The methodology to estimate monthly asset and liability positions combines, for each security type and country, holdings information collected on the periodic benchmark surveys with data on capital flows, valuation adjustments, asset-backed repayments, and merger-related stock swaps. For claims, the methodology effectively deals with the financial center bias identified in Warnock and Cleaver (2003) and discussed further in Griever, Lee, and Warnock (2001) and Bertaut, Griever, and Tryon (2006). For liabilities, the custodial center bias in the benchmark holdings data means that any geographic bias is not completely alleviated.

Benchmark surveys. The starting point for the position estimates is the information on crossborder securities holdings collected as part of the periodic TIC benchmark asset and liability surveys. Our estimates of the foreign securities holdings of U.S. investors use information available from the asset surveys conducted in March 1994 and year-end 1997, 2001, 2003, 2004, and 2005; for U.S. securities holdings of foreign investors we use information available from the liability surveys conducted as of December 1994, December 1997, March 2000, and June of 2002, 2003, 2004, 2005, and 2006. This information includes the unique security-level identifier, so asset type and country of issuer are accurately identified.

\footnotetext{
${ }^{17}$ See also Warnock and Warnock (2006).
} 
Valuation adjustments. The position estimates are adjusted for valuation changes using price indices related to the total return indices closely associated with each security type. For equities, the MSCI index for each country is used. For foreign bonds, MSCI indexes are used for developed countries, while EMBI or GBI is appropriate for developing countries. At times a country does not have an EMBI or GBI, but bond returns might be available on Bloomberg. Survey data indicate that U.S. investors hold significant amounts of dollar-denominated debt in several developed countries. For these countries the valuation adjustment is a weighted average of the MSCI bond index, which is denominated in the local currency, and the MSCI Eurodollar Credit index, which is denominated in U.S. dollars. The average is weighted by the fraction of dollar-denominated debt held by U.S. investors in each country. For U.S. bonds, Lehman price indices are used: for Treasuries, government indices appropriate for the maturity structure; for corporates, ABS for asset-backed and corporate debt for non-ABS; and for agencies, MBS for asset-backed and government-sponsored agency for non-MBS. Some liabilities are not in USD, so the returns are adjusted for exchange rate changes.

Bilateral capital flows. The position estimates incorporate the cross-border securities transactions occurring each month. The TIC system collects the market value of gross purchases and sales of securities by asset type and location of the foreign counterparty to the transaction. U.S. domestic securities types reported include U.S. Treasury debt, U.S. government agency debt, debt issued by corporations and other institutions, and equity. Foreign securities are classified simply as debt or equity.

Asset-backed repayments. Many asset-backed securities, including some U.S. agency and corporate debt, include periodic principal repayments. While the correct market value of these securities is recorded on the benchmark surveys, the flows associated with principal repayments 
are not recorded in the TIC system. However, estimates of these repayments are published on the TIC website and used to construct the monthly position estimates.

Stock swaps. The TIC data also do not include equities acquired through merger-related stock swaps. As with asset-backed principal repayments, this information is available on the TIC website and used to construct the monthly position estimates.

\section{A.2 Methodology}

Using these data sources, the monthly cross-border position estimates are constructed in two steps: a naïve estimate and then a benchmark-consistent estimate. For cross-border portfolio holdings of U.S. investors, position estimates are constructed by asset type (equity or debt) and country. For the U.S. holdings of foreign investors, positions estimates are constructed for each country and equity or debt type (U.S. Treasuries, U.S. agency bonds, or corporate debt).

Nä̈ve estimates: Naïve estimates of monthly positions are constructed for the period between adjacent pairs of benchmark surveys. Starting with a benchmark survey position, there is an adjustment for price and exchange rate changes and the current month's capital flows. Reported flows data are adjusted; U.S. corporate and agency debt positions are adjusted for flows from asset-backed principal repayments, and equity positions are adjusted for net purchases and sales acquired through stock swaps. Specifically, the resulting naïve position estimates of each security type $i$ evolve according to the equation:

$$
n h_{i, t}=n h_{i, t-1}\left(1+r_{i, t}\right)+g p_{i, t}-g s_{i, t}+a b_{i, t}+s s_{i, t}
$$

where:

$n h_{i, t}$ naive estimate of the net position in security $i$ at the end of month $t$

$r_{i, t}$ return of security $i$ from period $t-1$ to $t$, computed from the appropriate price index

$g p_{i, t}$ gross purchases of security $i$ during month $t$

$g s_{i, t}$ gross sales of security $i$ during month $t$ 
$a b_{i, t}$ net flows from principal repayments on security $i$ during month $t$

$s s_{i, t}$ quantity of security $i$ acquired through stock swaps during month $t$.

Using (A1), naïve position estimates are constructed through the date of the next benchmark survey. The naïve estimate as of the next survey date, $n h_{i, T}$, generally differs from the holdings reported on the subsequent benchmark survey, $h_{i, T}$. The next step is to adjust the naïve position estimates for this difference.

Benchmark-consistent estimates: To construct benchmark-consistent monthly position estimates, the naïve estimates are adjusted to be consistent with the positions recorded on each benchmark survey. As previously mentioned, the naïve baseline estimate generally differs from the benchmark survey holdings by an amount gap $_{i, T}$, such that:

$$
\operatorname{gap}_{i, T}=h_{i, T}-n h_{i, T}
$$

Our estimates use an adjustment that assumes that this gap is caused by errors in the capital flow data or returns and that these errors are larger in months with greater trading activity. With this adjustment, the benchmark-consistent position estimates between each pair of benchmark surveys evolve according to:

$$
h_{i, t}=h_{i, t-1}\left(1+r_{i, t}\right)+g p_{i, t}-g s_{i, t}+a b_{i, t}+s s_{i, t}+a d j_{i} * v a_{i, t}
$$

where $a d j_{i}$ is the constant adjustment factor for security $i$ between each pair of benchmark surveys, and $v a_{i, t}$ is the proportion of inter-survey trading activity that occurred in that month, such that:

$$
v a_{i, t}=\frac{g p_{i, t}+g s_{i, t}}{\sum_{k=1}^{T} g p_{i, k}+g s_{i, k}} .
$$


Combining (A1), (A2) and (A3), the survey gap can be expressed:

$$
\operatorname{gap}_{i, T}=h_{i, T}-n h_{i, T}=\left(h_{i, T-1}-n h_{i, T-1}\right)\left(1+r_{i, T}\right)+a d j_{i} * v a_{i, T} .
$$

The initial naïve holdings estimates are equal to the benchmark-consistent position estimates (i.e., $h_{i, 1}-n h_{i, 1}=0$ ). Thomas et. al. (2006) use a grid search method to solve for $a d j_{i}$. Alternatively (and equivalently), Bertaut and Tryon (2007) show that the assumption that errors are greater in months of greater trading volume $v a_{i, t}$ allows for an explicit solution of (A4) for $a d j$, such that:

$$
\operatorname{adj}_{i}=\frac{\operatorname{gap}_{i, T}}{\sum_{k=1}^{T}\left[v a_{i, k} \prod_{m=k+1}^{T}\left(1+r_{i, m}\right)\right]} .
$$

In effect, the end-of-period gap can be distributed between inter-survey months using each month's share of total transactions, discounted appropriately. Incorporating (A5) into (A3) provides a benchmark-consistent position estimate for each month. In our work we use a prelimary version of the soon to be publicly released Bertaut and Tryon (2007) data. ${ }^{18}$

\footnotetext{
${ }^{18}$ Compared to Thomas et al. (2006), the other innovation of Bertaut and Tryon (2007) is the use of morerefined returns indices (described above) to estimate the positions. This is important-a big source of improvements in holdings estimates will come from ever more-precise and more-specific returns data-but for now this is still a second-order improvement; the resulting estimates are nearly identical to those in Thomas et. al. (2006), with correlations as high as 0.999. Also, Bertaut and Tryon (2007) show that, for the purpose of forming monthly positions, estimates including an adjustment for transactions costs as in Thomas et. al.(2006) is unnecessary because it can be folded into the adjustment. For forming restated flows data as in Warnock and Warnock (2006), an adjustment for transaction costs is necessary.
} 


\section{Appendix B. Details of Data Underlying IIP and Partially Revised Returns Estimates}

This section details the data used in constructing IIP and PR returns.

\section{B.1 IIP Returns}

The annual IIP presentation appears each year in the June or July edition of BEA's Survey of Current Business. Since 1983, Table 1 of each annual IIP decomposes the change in year-end positions into the contributions from net flows and valuation adjustments due to price

and exchange-rate changes as well as from "other changes". ${ }^{19}$ Although line numbers vary over time, claims positions are always reported separately for foreign bonds and stocks. Liabilities positions are reported separately for foreign official holdings of U.S. Treasuries, other government (primarily agency debt), and other foreign official assets (which includes equities and corporate bonds). ${ }^{20}$ Liabilities to private foreigners are reported separately for U.S. Treasuries, corporate and other bonds, and equities.

For international income streams, we use series on U.S. equity and debt income payments and receipts that BEA provides to the IMF (IMF SDDS fields 2340, 2350, 3340, 3352, and 3354). These data have been reported since 1986 .

\section{B.2 Partially-Revised Returns}

The revised position estimates by product for 1976-2005 are available in Table 2 of the International Investment Position area of the BEA website (www.bea.gov/international). Revised flow estimates from 1982-2005 are available from the Balance of Payments area of the same website. From 1998-2005 the flow estimates by security type are reported in Table 7a, from 1982-1997 in Table 7b. Prior to 1982 flows were reported by BEA to the IMF (SDDS fields 4610, 4620, 4660, 4670).

\footnotetext{
${ }^{19}$ Prior to 1983 the year-end IIP positions were reported in Table 3 of the IIP, while the contributions of flows, and price, exchange-rate and other changes were reported in Table 2.

${ }^{20}$ When we report bonds and stocks separately, we assume that half the securities in other foreign official assets are stocks, the balance bonds. This assumption does not impact total liability returns.
} 


\section{References:}

Ammer, J., S. Holland, D. Smith, and F. Warnock, 2006, Look at me now: The role of crosslistings in attracting U.S. shareholders. NBER Working Paper 12500.

Bertaut, Carol C., William L. Griever, and Ralph W. Tryon, 2006, Understanding U.S. crossborder securities data, Federal Reserve Bulletin, Board of Governors of the Federal Reserve System.

Bertaut, Carol C. and Ralph W. Tryon, 2007, Monthly estimates of U.S. cross-border securities positions, working paper.

Bohn, H., and L. Tesar, 1996, U.S. equity investment in foreign markets: Portfolio rebalancing or returns chasing? American Economic Review 86(2), 77-81.

Burger, J., and F. Warnock, 2007, Foreign participation in local currency bond markets, Review of Financial Economics (forthcoming).

Cavallo, Michele, and Cedric Tille, 2006, Could capital gains smooth a current account rebalancing? Federal Reserve Bank of New York Staff Reports, no. 237.

Choe, Hyuk, Bong-Chan Kho, and René M. Stulz, 2005, Do Domestic Investors Have an Edge? The Trading Experience of Foreign Investors in Korea, Review of Financial Studies 2005 18(3):795-829.

Devereaux, Michael B. and Makoto Saito,2006. A Portfolio Theory of International Capital Flows, Institute for International Integration Studies Discussion Paper No. 124.

Dvorak, Tomas, 2005. Do domestic investors have an information advantage? Evidence from Indonesia, Journal of Finance 60, 817-839.

Ferson, Wayne, and Kenneth Khang, 2002, Conditional performance measurement using portfolio weights: Evidence for pension funds, Journal of Financial Economics 65, 249282.

Ferson, W. and R. Schadt, 1996, Measuring fund strategy and performance in changing economic conditions, Journal of Finance 51(2), 425-461.

Forbes, Kristin, 2006, Global Imbalances: A Source of Strength or Weakness?, Comments at the Cato Institute $24^{\text {th }}$ Annual Monetary Conference.

Forbes, Kristin, 2007, Why do foreigners really invest in the United States? manuscript.

Ghironi, Fabio, Jaewoo Lee, and Alessandro Rebucci, 2006, The valuation channel of external adjustment, working paper.

Gourinchas, Pierre-Olivier and Helene Rey, 2006a (forthcoming), From world banker to world venture capitalist: The U.S. external adjustment and the exorbitant privilege, in R. Clarida 
(ed.) G7 Current Account Imbalances: Sustainability and Adjustment (Chicago, Univeristy of Chicago Press).

Gourinchas, Pierre-Olivier and Helene Rey, 2006b, International financial adjustment, working paper.

Griever, W., G. Lee, and F. Warnock, 2001, The U.S. system for measuring cross-border investment in securities: A primer with a discussion of recent developments. Federal Reserve Bulletin 87(10), 633-650.

Grinblatt, Mark and Sheridan Titman, 1993, Performance measurement without benchmarks: An examination of mutual fund returns, Journal of Business 66, 47-68.

Gros, Daniel, 2006, Why the U.S. Current Account Deficit is Not Sustainable, International Finance 9(2), 241-260.

Hausmann, Ricardo and Federico Sturzenegger, 2006, Global imbalances or bad accounting? The missing dark matter in the wealth of nations, CID working paper \# 124.

Heath, A., 2007, What explains the U.S. net income balance? BIS Working Papers No 223.

Higgins, Matthew, Thomas Klitgaard and Cedric Tille, 2006, Borrowing without debt? Understanding the U.S. international investment position, Federal Reserve Bank of New York Staff Report 271.

Hung, J., and A. Mascaro, 2004, Return on cross-border investment: Why does U.S. investment abroad do better? CBO Technical Paper Series 2004-17.

Kho, B.-C., R. Stulz, and F. Warnock, 2006, Financial globalization, governance, and the evolution of the home bias. NBER Working Paper 12386.

Lane, Philip R., and Gian Maria Milesi-Ferretti, 2005a, Financial Globalization and Exchange Rates, IMF working paper \# 05/3.

Lane, Philip R., and Gian Maria Milesi-Ferretti, 2005b, A global perspective on external positions, NBER working paper \# 11589.

Lane, Philip R., and Gian Maria Milesi-Ferretti, 2006, The external wealth of nations mark II: Revised and extended estimates of foreign assets and liabilities, 1970-2004, IMF Working paper \#WP/06/69.

Mattaloni, R., 2000, An examination of the low return of foreign-owned U.S. companies, Survey of Current Business (March): 55-73.

Meissner, Christopher M. and Alan M. Taylor, 2006, Losing our marbles in the new centrury? The great rebalancing in historical perspective, NBER Working Paper \#12580.

Mendoza, Enrique G., Vincenzo Quadrini, and Jose-Victor Rios-Rull, 2006, Financial intergration, financial deepness and global imbalances, working paper. 
Obstfeld, Maurice, and Kenneth S. Rogoff, 2005, Global Current Account Imbalances and Exchange Rate Adjustments, Brookings Papers on Economic Activity 1:2005, 67-123.

Thomas Charles P., Francis E. Warnock and Jon Wongswan, 2006, The performance of international equity portfolios, NBER Working Paper 12346.

Tille, Cedric, 2005, Financial integration and the wealth effect of exchange rate Fluctuations, FRBNY Staff Report - No. 226.

Tille, Cedric, and Eric van Wincoop, 2007. International capital flows. NBER Working Paper 12856.

Treasury Department, Federal Reserve Bank of New York, and Board of Governors of the Federal Reserve System, 2006a. Report on Foreign Holdings of U.S. Securities as of June 30, 2005.

Treasury Department, Federal Reserve Bank of New York, and Board of Governors of the Federal Reserve System, 2006b. Report on U.S. Holdings of Foreign Securities as of December 31, 2005.

Warnock, F., and C. Cleaver, 2003, Financial centers and the geography of capital flows. International Finance 6(1), 27-59.

Warnock, F. and V. Warnock, 2006, International capital flows and U.S. interest rates. NBER Working Paper 12560.

Wermers, Russ, 2006, Performance evaluation with portfolio holdings information, North American Journal of Economics and Finance 17, 207-230. 


\section{Table I}

\section{Country composition of U.S. portfolio of foreign equity and foreign bonds}

Country's weight in U.S. equity (bond) portfolio is the U.S. equity (bond) position in the country divided by the total U.S. equity (bond) position in all 38 countries included in the sample. Country's equity return is the average of simple monthly returns on MSCI gross U.S. dollar total return index expressed in percent. Developed countries' bond returns are the weighted averages of simple monthly U.S. dollar returns on the country's MSCI bond index and the MSCI Eurodollar Credit index where the weights on the Eurodollar index are the shares of dollar denominated bonds in U.S. holdings of foreign bonds. Emerging markets' bond returns are simple monthly returns on the EMBI+ U.S. dollar index. The time period is from January 1994 through December 2005 unless otherwise noted in the last column.

\begin{tabular}{|c|c|c|c|c|c|}
\hline Country & $\begin{array}{l}\text { Country's Avg. } \\
\text { Weight in U.S. } \\
\text { Equity Portfolio }\end{array}$ & $\begin{array}{l}\text { Country's Avg. } \\
\text { Equity Return }\end{array}$ & $\begin{array}{l}\text { Country's Avg. } \\
\text { Weight in U.S. } \\
\text { Bond Portfolio }\end{array}$ & $\begin{array}{c}\text { Country's } \\
\text { Avg. Bond } \\
\text { Return } \\
\end{array}$ & $\begin{array}{c}\text { Country } \\
\text { Included } \\
\text { from }\end{array}$ \\
\hline Australia & 0.030 & 1.076 & 0.037 & 0.567 & Jan '94 \\
\hline Austria & 0.003 & 0.939 & 0.005 & 0.598 & Jan '94 \\
\hline Belgiumlux & 0.010 & 1.078 & 0.022 & 0.597 & Jan '94 \\
\hline Canada & 0.071 & 1.225 & 0.227 & 0.574 & Jan '94 \\
\hline Denmark & 0.006 & 1.239 & 0.016 & 0.649 & Jan '94 \\
\hline Finland & 0.023 & 2.023 & 0.009 & 0.600 & Jan '94 \\
\hline France & 0.076 & 0.964 & 0.049 & 0.573 & Jan '94 \\
\hline Germany & 0.056 & 0.896 & 0.092 & 0.565 & Jan '94 \\
\hline Greece & 0.002 & 1.346 & 0.003 & 0.720 & Jun '97 \\
\hline Ireland & 0.013 & 0.971 & 0.010 & 0.651 & Jan '94 \\
\hline Italy & 0.029 & 1.165 & 0.036 & 0.750 & Jan '94 \\
\hline Japan & 0.158 & 0.329 & 0.072 & 0.262 & Jan '94 \\
\hline Netherlands & 0.081 & 0.969 & 0.051 & 0.565 & Jan '94 \\
\hline Norway & 0.007 & 1.226 & 0.010 & 0.639 & Jan '94 \\
\hline Portugal & 0.003 & 0.923 & 0.002 & 0.701 & Jan '94 \\
\hline Spain & 0.024 & 1.343 & 0.018 & 0.689 & Jan '94 \\
\hline Sweden & 0.026 & 1.505 & 0.025 & 0.698 & Jan '94 \\
\hline Switzerland & 0.055 & 1.055 & 0.002 & 0.544 & Jan '94 \\
\hline U. K. & 0.213 & 0.813 & 0.136 & 0.618 & Jan '94 \\
\hline Argentina & 0.006 & 1.112 & 0.029 & -0.347 & Jan'94 \\
\hline Brazil & 0.018 & 1.966 & 0.027 & 0.622 & Jan '94 \\
\hline Chile & 0.003 & 0.965 & 0.010 & 0.223 & Jun '99 \\
\hline China & 0.003 & -0.086 & 0.004 & 0.152 & Apr '94 \\
\hline Colombia & 0.000 & 1.857 & 0.006 & 0.209 & Mar '97 \\
\hline Hungary & 0.002 & 2.225 & 0.001 & -0.019 & Feb '99 \\
\hline India & 0.006 & 0.994 & 0.001 & 0.095 & Mar '96 \\
\hline Korea & 0.019 & 1.458 & 0.015 & 0.057 & Jan '94 \\
\hline Malaysia & 0.007 & 0.333 & 0.007 & 0.148 & Nov'96 \\
\hline Mexico & 0.026 & 1.202 & 0.050 & 0.225 & Jan '94 \\
\hline Morocco & 0.000 & 0.980 & 0.001 & 0.332 & Jan '95 \\
\hline Peru & 0.001 & 1.618 & 0.002 & 0.994 & Jan '94 \\
\hline Philippine & 0.003 & -0.127 & 0.006 & 0.213 & Jan '94 \\
\hline Poland & 0.001 & 1.063 & 0.003 & 0.467 & Jan '94 \\
\hline Russia & 0.004 & 3.406 & 0.007 & 1.393 & Jan '95 \\
\hline South Africa & 0.009 & 1.267 & 0.004 & 0.248 & Jun '94 \\
\hline Thailand & 0.005 & 0.331 & 0.004 & 0.130 & Jun '97 \\
\hline Turkey & 0.002 & 2.167 & 0.003 & 0.355 & Jul ‘96 \\
\hline Venezuela & 0.001 & 1.319 & 0.010 & 0.632 & Jan '94 \\
\hline
\end{tabular}




\section{Table II}

\section{Characteristics of U.S. foreign claims and liabilities}

Equity weight in U.S. claims is the share of foreign equities in U.S. investors' foreign bond and equities portfolio. Equity weight in U.S. liabilities is the share of U.S. equities in foreign investors' U.S. bond and equities portfolio. Returns on U.S. equities are the monthly simple returns on the U.S. MSCI gross return equity index. Returns on U.S. bonds are foreign-portfolio-weighted averages of Lehman Brothers Treasury, Corporate and Agency bond indices. Returns on foreign equities are U.S.-portfolio-weighted averages of each country's simple monthly dollar return on its MSCI gross return equity index. Returns on foreign bonds are U.S.-portfolio-weighted averages of each country's bond returns. Developed countries' bond returns are the weighted averages of simple monthly U.S. dollar returns on the country's MSCI bond index and the MSCI Eurodollar Credit index where the weights on the Eurodollar index are the shares of dollar denominated bonds in U.S. holdings of foreign bonds. Emerging markets' bond returns are simple monthly returns on the EMBI+ U.S. dollar index. All data are from January 1994 through December 2005, unless otherwise noted in Table I.

\begin{tabular}{|c|c|c|c|c|c|}
\hline & Mean & Median & St.Dev. & Min & Max \\
\hline \multicolumn{6}{|c|}{ Panel A: Equity Weight in U.S. Claims (\%) } \\
\hline All Countries & 70.8 & 71.1 & 3.8 & 62.7 & 78.3 \\
\hline Developed Countries & 72.3 & 72.7 & 4.5 & 62.1 & 81.1 \\
\hline Emerging Markets & 60.2 & 60.6 & 6.7 & 44.9 & 75.9 \\
\hline \multicolumn{6}{|c|}{ Panel B: Equity Weight in U.S. Liabilities (\%) } \\
\hline All Countries & 41.7 & 39.4 & 5.9 & 33.9 & 54.4 \\
\hline Developed Countries & 45.8 & 42.8 & 6.0 & 39.0 & 59.1 \\
\hline Emerging Markets & 9.0 & 9.4 & 2.8 & 4.0 & 14.5 \\
\hline \multicolumn{6}{|c|}{ Panel C: Equity Returns (\% per month) } \\
\hline Return on U.S. Equities & 0.940 & 1.318 & 4.306 & -13.905 & 9.984 \\
\hline \multicolumn{6}{|l|}{ Return on Foreign Equities } \\
\hline All Countries & 0.766 & 1.221 & 4.321 & -14.791 & 10.726 \\
\hline Developed Countries & 0.797 & 1.068 & 4.169 & -13.004 & 10.540 \\
\hline Emerging Markets & 0.849 & 2.181 & 7.433 & -32.656 & 16.408 \\
\hline \multicolumn{6}{|c|}{ Panel D: Bond Returns (\% per month) } \\
\hline \multicolumn{6}{|l|}{ Return on U.S. Bonds } \\
\hline By All Countries & 0.478 & 0.576 & 0.922 & -2.769 & 2.957 \\
\hline By Developed Countries & 0.484 & 0.594 & 0.954 & -2.948 & 3.013 \\
\hline By Emerging Markets & 0.451 & 0.481 & 0.794 & -2.123 & 2.502 \\
\hline \multicolumn{6}{|l|}{ Return on Foreign Bonds } \\
\hline All Countries & 0.493 & 0.511 & 1.620 & -4.641 & 5.528 \\
\hline Developed Countries & 0.567 & 0.451 & 1.605 & -3.558 & 5.149 \\
\hline Emerging Markets & 0.197 & 0.716 & 3.798 & -22.812 & 8.822 \\
\hline
\end{tabular}




\section{Table III}

\section{Returns on U.S. Claims and Liabilities}

All returns are monthly averages from January 1994 to December 2005, expressed in percent. Hypothetical returns are average portfolio weights times average returns; average weights and returns are from Table II. Actual returns are computed from the actual monthly portfolio weights. Standard t-statistics are in parentheses. Bootstrapped z-statistics based on 1000 draws are in brackets.

\begin{tabular}{lcc}
\hline & Hypothetical & Actual \\
\hline All Countries & & \\
U.S. Claims & 0.686 & 0.668 \\
U.S. Liabilities & 0.671 & 0.612 \\
$\quad$ Difference & 0.015 & 0.056 \\
$\quad$ z- or t-statistic & {$[0.09]$} & $(0.31)$ \\
\hline Developed Countries & & \\
U.S. Claims & 0.733 & 0.712 \\
U.S. Liabilities & 0.692 & 0.627 \\
$\quad$ Difference & 0.041 & 0.084 \\
$\quad$ z- or t-statistic & {$[0.25]$} & $(0.48)$ \\
\hline Emerging Markets & & \\
U.S. Claims & 0.590 & 0.599 \\
U.S. Liabilities & 0.495 & 0.489 \\
$\quad$ Difference & 0.095 & 0.110 \\
z- or t-statistic & {$[0.20]$} & $(0.25)$ \\
\hline
\end{tabular}




\section{Table IV}

\section{Decomposition of the Return Differential into Composition, Return and Timing Effects}

Difference, the difference between the average monthly percentage return on the portfolio of U.S. claims (foreign equities and U.S. bonds) and the return on U.S. liabilities (U.S. equities and U.S. bonds), equals Composition Effect plus Return Effect minus Foreign Timing Effect plus U.S. Timing Effect. The composition, return and timing effects are defined in section 2.1. Standard t-statistics are in parentheses. Bootstrapped z-statistics based on 1000 draws are in brackets. Statistical significance at the 1, 5, and 10 percent levels are denoted by ***,**, and *, respectively.

\begin{tabular}{|c|c|c|c|c|}
\hline \multirow{2}{*}{$\begin{array}{c}\text { Difference } \\
\text { (claims-liabilities) }\end{array}$} & \multirow{2}{*}{ Composition Effect } & \multirow{2}{*}{ Return Effect } & \multicolumn{2}{|c|}{ Timing Effects } \\
\hline & & & Foreign & U.S. \\
\hline \multicolumn{5}{|c|}{ Panel A: All Countries } \\
\hline 0.056 & 0.107 & -0.091 & $-0.058 * *$ & -0.018 \\
\hline$(0.31)$ & [1.07] & {$[-0.60]$} & $(-2.67)$ & $(-1.48)$ \\
\hline \multicolumn{5}{|c|}{ Panel B: Vis-à-vis Private Foreign Positions } \\
\hline-0.002 & 0.074 & -0.112 & $-0.053 * *$ & -0.018 \\
\hline$(-0.01)$ & [1.12] & {$[-0.62]$} & $(-2.67)$ & $(-1.44)$ \\
\hline \multicolumn{5}{|c|}{ Panel C: Developed Countries } \\
\hline 0.084 & 0.091 & -0.050 & $-0.065 * *$ & -0.022 \\
\hline$(0.48)$ & {$[1.00]$} & {$[-0.33]$} & $(-2.97)$ & $(-1.46)$ \\
\hline \multicolumn{5}{|c|}{ Panel D: Emerging Market Countries } \\
\hline 0.11 & 0.292 & -0.197 & -0.006 & 0.009 \\
\hline$(0.25)$ & [1.45] & {$[-0.60]$} & $(-0.72)$ & $(0.27)$ \\
\hline
\end{tabular}




\section{Table V}

\section{Decomposing the Timing Effect into Trading and Passive Effects}

The covariance between lagged weights and returns (the timing effect) is decomposed into (1) the covariance between lagged deviations of actual from buy-and-hold weights and subsequent returns (the trading effect), and (2) the covariance of the lagged deviation of buy-and-hold weights from average weights and subsequent returns. Lag indicates the horizon of the buy-and-hold weight in months. Tstatistics are in parentheses. Statistical significance at the 1, 5, and 10 percent levels are denoted by $* * *, * *$, and $*$, respectively.

\begin{tabular}{|c|c|c|c|c|c|}
\hline \multirow{2}{*}{ Lag } & \multicolumn{2}{|c|}{ Foreign Timing Effect } & \multicolumn{2}{|c|}{ U.S. Timing Effect } & \multirow{2}{*}{$\begin{array}{l}\text { \# of } \\
\text { obs }\end{array}$} \\
\hline & Trading Effect & Passive Effect & Trading Effect & Passive Effect & \\
\hline \multicolumn{6}{|c|}{ Panel A: All Countries } \\
\hline 6 & $\begin{array}{c}-0.011 * * \\
(-2.03)\end{array}$ & $\begin{array}{c}-0.049 * * \\
(-2.45)\end{array}$ & $\begin{array}{c}0.003 \\
(0.69)\end{array}$ & $\begin{array}{l}-0.019 \\
(-1.57)\end{array}$ & 138 \\
\hline 12 & $\begin{array}{c}-0.034 * * * \\
(-3.38)\end{array}$ & $\begin{array}{l}-0.029 \\
(-1.59)\end{array}$ & $\begin{array}{l}0.000 \\
(0.05)\end{array}$ & $\begin{array}{l}-0.016 \\
(-1.34)\end{array}$ & 132 \\
\hline 24 & $\begin{array}{c}-0.061 * * * \\
(-3.48)\end{array}$ & $\begin{array}{l}-0.001 \\
(-0.03) \\
\end{array}$ & $\begin{array}{l}-0.003 \\
(-0.37) \\
\end{array}$ & $\begin{array}{l}-0.015 \\
(-1.04) \\
\end{array}$ & 120 \\
\hline \multicolumn{6}{|c|}{ Panel B: Developed Countries } \\
\hline 6 & $\begin{array}{c}-0.011^{*} \\
(-1.93)\end{array}$ & $\begin{array}{c}-0.057 * * * \\
(-2.85)\end{array}$ & $\begin{array}{l}0.004 \\
(0.99)\end{array}$ & $\begin{array}{l}-0.023 \\
(-1.56)\end{array}$ & 138 \\
\hline 12 & $\begin{array}{c}-0.032 * * * \\
(-3.17)\end{array}$ & $\begin{array}{c}-0.038 * * \\
(-2.15)\end{array}$ & $\begin{array}{l}0.003 \\
(0.61)\end{array}$ & $\begin{array}{l}-0.022 \\
(-1.51)\end{array}$ & 132 \\
\hline 24 & $\begin{array}{c}-0.059 * * * \\
(-3.31) \\
\end{array}$ & $\begin{array}{r}-0.007 \\
(-0.37) \\
\end{array}$ & $\begin{array}{l}0.006 \\
(1.10) \\
\end{array}$ & $\begin{array}{c}-0.028^{*} \\
(-1.71) \\
\end{array}$ & 120 \\
\hline \multicolumn{6}{|c|}{ Panel C: Emerging Market Countries } \\
\hline 6 & $\begin{array}{c}-0.007 * \\
(-1.91)\end{array}$ & $\begin{array}{l}0.001 \\
(0.12)\end{array}$ & $\begin{array}{l}0.013 \\
(0.93)\end{array}$ & $\begin{array}{l}-0.009 \\
(-0.23)\end{array}$ & 138 \\
\hline 12 & $\begin{array}{c}-0.021 * * * \\
(-3.34)\end{array}$ & $\begin{array}{l}0.013 \\
(1.29)\end{array}$ & $\begin{array}{l}0.023 \\
(1.19)\end{array}$ & $\begin{array}{l}-0.019 \\
(-0.44)\end{array}$ & 132 \\
\hline 24 & $\begin{array}{c}-0.029 * * \\
(-2.39) \\
\end{array}$ & $\begin{array}{l}0.018 \\
(1.07) \\
\end{array}$ & $\begin{array}{l}-0.016 \\
(-0.67) \\
\end{array}$ & $\begin{array}{l}0.029 \\
(0.62) \\
\end{array}$ & 120 \\
\hline
\end{tabular}




\section{Table VI}

Trading and Passive Effects of Aggregate Foreign Private Investors in the U.S.

The calculations in this table use aggregate private foreign positions in the U.S. The covariance between lagged weights and returns (the timing effect) is decomposed into (1) the covariance between lagged deviations of actual from buy-and-hold weights and subsequent returns (the trading effect), and (2) the covariance of the lagged deviation of buy-and-hold weights from average weights and subsequent returns. Lag indicates the horizon of the buy-and-hold weight in months.. T-statistics are in parentheses. Statistical significance at the 1,5 , and 10 percent levels are denoted by ***,**, and *, respectively.

\begin{tabular}{|c|c|c|c|}
\hline \multirow[b]{2}{*}{ Lag } & \multicolumn{2}{|c|}{ Foreign Private Timing Effect } & \multirow{2}{*}{$\begin{array}{l}\# \text { of } \\
\text { obs }\end{array}$} \\
\hline & Trading Effect & Passive Effect & \\
\hline 6 & $\begin{array}{c}-0.013 * * \\
(-2.45)\end{array}$ & $\begin{array}{c}-0.042 * * \\
(-2.26)\end{array}$ & 138 \\
\hline 12 & $\begin{array}{c}-0.032 * * * \\
(-3.58)\end{array}$ & $\begin{array}{l}-0.024 \\
(-1.42)\end{array}$ & 132 \\
\hline 24 & $\begin{array}{c}-0.058 * * * \\
(-3.49)\end{array}$ & $\begin{array}{l}0.003 \\
(0.11)\end{array}$ & 120 \\
\hline
\end{tabular}




\section{Table VII}

\section{Decomposition of the Return Differential into Composition, Return and Timing Effects:}

\section{Subsamples}

Difference, the difference between the average monthly percentage return on the portfolio of U.S. claims (foreign equities and U.S. bonds) and the return on U.S. liabilities (U.S. equities and U.S. bonds), equals Composition Effect plus Return Effect minus Foreign Timing Effect plus U.S. Timing Effect. The composition, return and timing effects are defined in section 2.1. Standard t-statistics are in parentheses. Bootstrapped z-statistics based on 1000 draws are in brackets. Statistical significance at the 1, 5, and 10 percent levels are denoted by ***, **, and *, respectively.

\begin{tabular}{ccccc}
\hline $\begin{array}{c}\text { Difference } \\
\text { (claims-liabilities) }\end{array}$ & Composition Effect & Return Effect & \multicolumn{2}{c}{ Timing Effects } \\
& & Panel A: $1994-1999$ & & U.S. \\
\hline-0.127 & $0.304 * * *$ & $-0.452^{* *}$ & -0.009 & 0.012 \\
$(-0.41)$ & {$[3.01]$} & {$[-2.14]$} & $(-0.39)$ & -0.83 \\
\hline \multicolumn{5}{c}{ Panel B: $2000-2005$} \\
\hline 0.239 & -0.115 & 0.279 & $-0.106^{* * *}$ & -0.032 \\
$(0.92)$ & {$[-0.74]$} & {$[1.46]$} & $(-2.88)$ & $(-1.58)$ \\
\hline
\end{tabular}




\section{Table VIII}

\section{Decomposing the Timing Effect into Skill and Passive Strategy: Subsamples}

The covariance between lagged weights and returns (the timing effect) is decomposed into (1) the covariance between lagged deviations of actual from buy-and-hold weights and subsequent returns (the trading effect), and (2) the covariance of the lagged deviation of buy-and-hold weights from average weights and subsequent returns. Lag indicates the horizon of the buy-and-hold weight in months. Tstatistics are in parentheses. Statistical significance at the 1, 5, and 10 percent levels are denoted by $* * *, * *$, and *, respectively.

\begin{tabular}{|c|c|c|c|c|c|}
\hline \multirow{2}{*}{ Lag } & \multicolumn{2}{|c|}{ Foreign Timing } & \multicolumn{2}{|c|}{ U.S. Timing } & \multirow{2}{*}{ Nobs } \\
\hline & Trading Effect & Passive Effect & Trading Effect & Passive Effect & \\
\hline \multicolumn{6}{|c|}{ Panel A: 1994 -1999 } \\
\hline 6 & $\begin{array}{l}-0.013 \\
(-1.74)\end{array}$ & $\begin{array}{l}0.004 \\
(0.18)\end{array}$ & $\begin{array}{c}0.008 \\
(1.29)\end{array}$ & $\begin{array}{l}0.010 \\
(0.65)\end{array}$ & 66 \\
\hline 12 & $\begin{array}{c}-0.037 * * * \\
(-2.53)\end{array}$ & $\begin{array}{l}0.029 \\
(1.37)\end{array}$ & $\begin{array}{l}0.011 \\
(1.22)\end{array}$ & $\begin{array}{l}0.012 \\
(0.70)\end{array}$ & 60 \\
\hline 24 & $\begin{array}{c}-0.071^{* *} * \\
(-2.25)\end{array}$ & $\begin{array}{l}0.080^{*} \\
(2.10) \\
\end{array}$ & $\begin{array}{c}0.015^{*} \\
(1.64) \\
\end{array}$ & $\begin{array}{l}0.011 \\
(0.56) \\
\end{array}$ & 48 \\
\hline \multicolumn{6}{|c|}{ Panel B: 2000-2005 } \\
\hline 6 & $\begin{array}{l}-0.011 \\
(-1.19)\end{array}$ & $\begin{array}{c}-0.095 * * * \\
(-3.06)\end{array}$ & $\begin{array}{l}-0.003 \\
(-0.55)\end{array}$ & $\begin{array}{l}-0.029 \\
(-1.36)\end{array}$ & 66 \\
\hline 12 & $\begin{array}{c}-0.030^{*} \\
(-1.94)\end{array}$ & $\begin{array}{c}-0.054 * * * \\
(-2.77)\end{array}$ & $\begin{array}{l}-0.009 \\
(-1.00)\end{array}$ & $\begin{array}{l}-0.014 \\
(-0.62)\end{array}$ & 60 \\
\hline 24 & $\begin{array}{c}-0.047 * \\
(-2.06)\end{array}$ & $\begin{array}{l}-0.013 \\
(-0.57)\end{array}$ & $\begin{array}{l}-0.007 \\
(-0.51)\end{array}$ & $\begin{array}{l}-0.008 \\
(-0.21)\end{array}$ & 48 \\
\hline
\end{tabular}




\section{Table IX}

\section{Average annual total returns on claims and liabilities}

Total returns consist of returns on capital gains and income streams. For capital gains, returns in the IIP column use capital gains implied using the valuation adjustments due to price and exchange-rate changes reported on each annual IIP. The totals are divided by the IIP position at the start of the year, plus half of the year's IIP flows. Returns in the PR column use capital gains implied from the revised position and flow series available on the BEA website. For each year, the implied capital gain is the change in the revised position from the start of the year to the end of the year, less the revised flows that occur during the year and the valuation adjustments from other changes reported on the IIP. These implied capital gains are divided by the revised position at the start of the year, plus half of the year's revised flows. For both IIP and PR total returns we add the relevant income as reported to the IMF by BEA to the capital gains as estimated above. The CDW total return is the annual compound return computed using our position estimates and returns. The differential return between claims and liabilities is computed by weighting the products using the average year-end IIP positions for the IIP differential, and the average year-end revised position estimate for the partially-revised differential. The CDW differential weights claims and liabilities by the average weight for each year. All data are expressed as percentages.

\begin{tabular}{llccc}
\hline & & IIP & PR & CDW \\
\hline \multirow{2}{*}{ Equity } & Panel A: 1986-2005 & & \\
& Claims & 13.1 & 21.7 & \\
& Liabilities & 13.8 & 14.7 & \\
& Claims & 9.3 & 13.7 & \\
& Liabilities & 8.7 & 7.9 & \\
& & & & \\
\hline \multirow{2}{*}{ Equity } & Claifferential & 1.4 & 8.0 & \\
& & Panel B: $1994-2005$ & & 9.8 \\
\multirow{3}{*}{ Bond } & 9.2 & 12.2 & 12.5 \\
& Liabilities & 12.0 & 14.0 & 6.1 \\
& Claims & 5.6 & 9.7 & 5.9 \\
& Liabilities & 5.7 & 3.0 & \\
& & & & 0.4 \\
\hline
\end{tabular}




\section{Figure 1}

\section{U.S. equity and bond returns and the equity weight in U.S. portfolio liabilities}

The 12-month total return on U.S. equities is the return on the MSCI U.S. total return index. The 12-month total return on U.S. bonds is the foreign-portfolio-weighted average of Lehman Brothers Treasury, Corporate and Agency bond returns. Actual equity weight in U.S. portfolio liabilities is the share of U.S. equities in foreign investors' U.S. bond and equities portfolio. The 24-month buy-and-hold weight is the share of equity that would have resulted from a buy-and-hold strategy adopted 24 months ago.
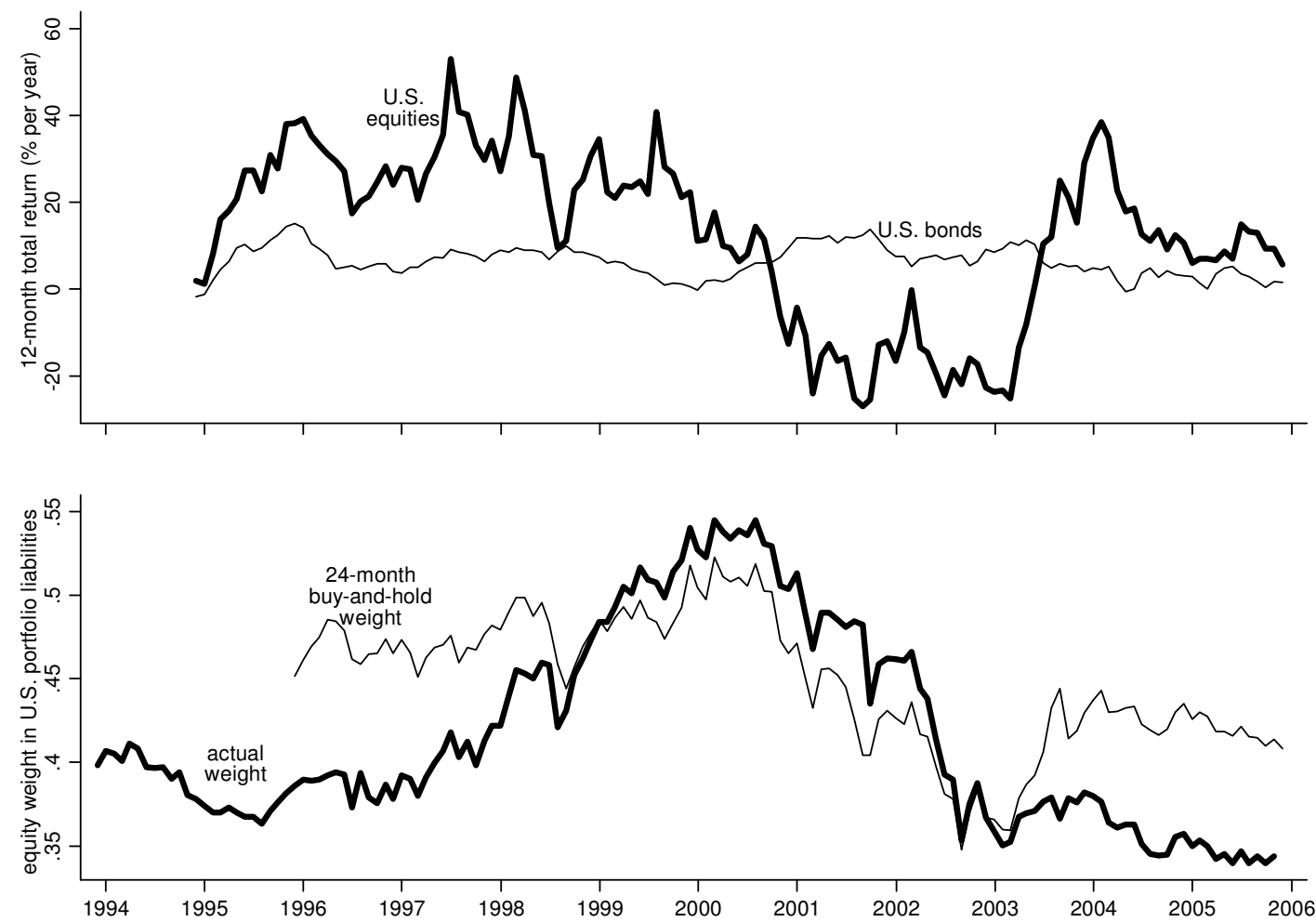


\section{Figure 2}

\section{Foreign equity and bond returns and the equity weight in U.S. portfolio claims}

The 12-month total return on foreign equities is the U.S.-portfolio-weighted average of each country's dollar return on its MSCI gross return equity index. The 12-month total returns on foreign bonds are U.S.portfolio-weighted averages of each country's bond returns. Developed countries' bond returns are the weighted averages of simple monthly U.S. dollar returns on the country's MSCI bond index and the MSCI Eurodollar Credit index where the weights on the Eurodollar index are the shares of dollar denominated bonds in U.S. holdings of foreign bonds. Emerging markets' bond returns are simple monthly returns on the EMBI+ U.S. dollar index. foreign bonds is the U.S.-portfolio-weighted average of the MSCI (for developed countries) or EMBI+ (for emerging markets) bond return indices. Actual equity weight in U.S. claims is the share of foreign equities in U.S. investors' foreign bond and equities portfolio. The 24-month buy-and-hold weights is the share of equity that would have resulted from a buy-and-hold strategy adopted 24 months ago.
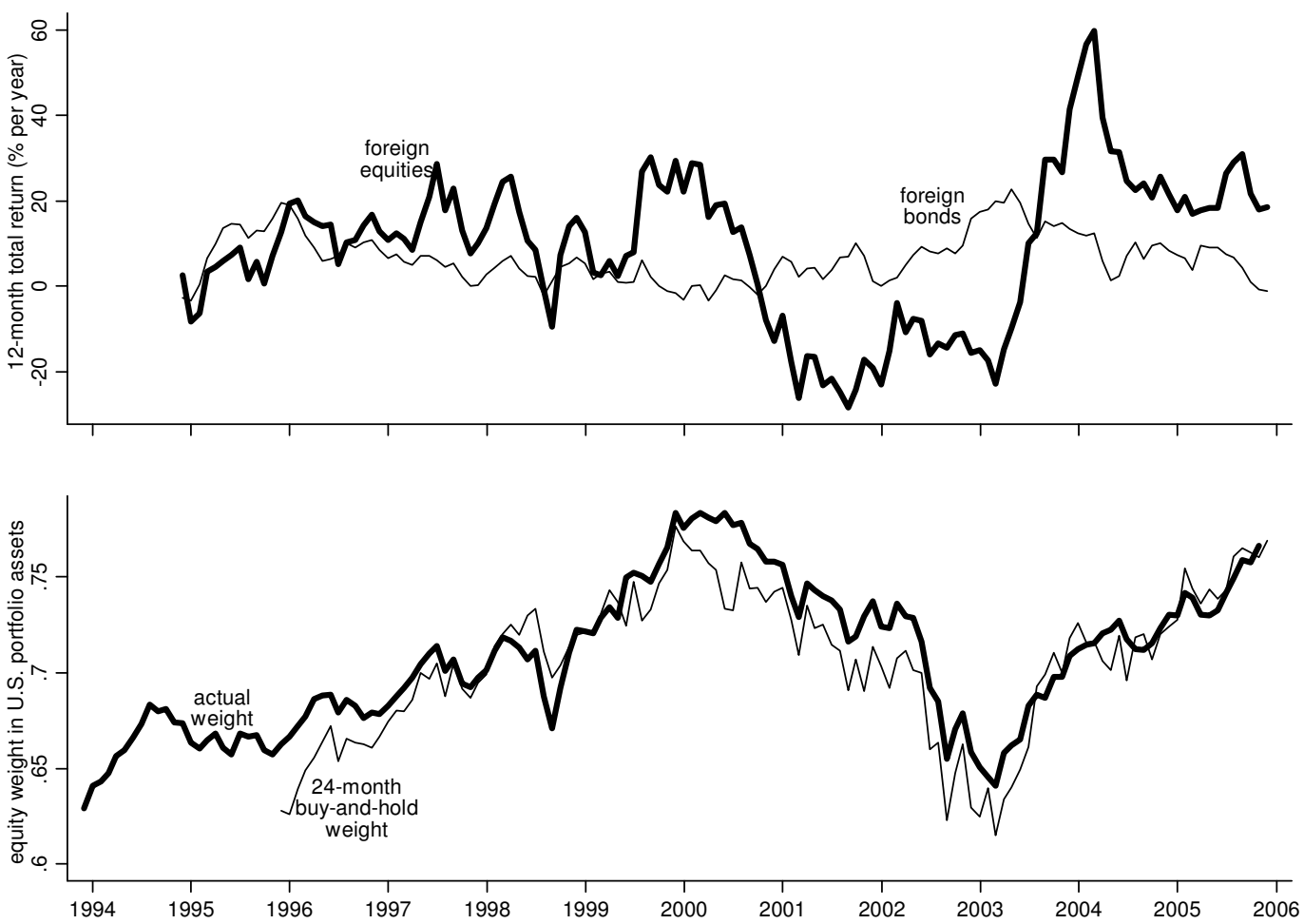


\section{Figure 3}

\section{Total returns on U.S. holdings of foreign bonds and equity}

In the IIP method capital gains are implied using the valuation adjustments due to price and exchange-rate changes reported on each annual IIP. We add the relevant income as reported to the IMF by BEA to the capital gains as estimated above. These total returns are divided by the IIP position at the start of the year, plus half of the year's IIP flows. In the partially-revised method, capital gains implied from the revised position and flow series available on the BEA website. For each year, the implied capital gain is the change in the revised position from the start of the year to the end of the year, less the revised flows that occur during the year and the valuation adjustments from other changes reported on the IIP. The same income series is added. These total returns are divided by the revised position at the start of the year, plus half of the year's revised flows. The CDW total return is the annual compound return computed using our position estimates and returns.

\section{U.S. Holdings of Foreign Bonds}

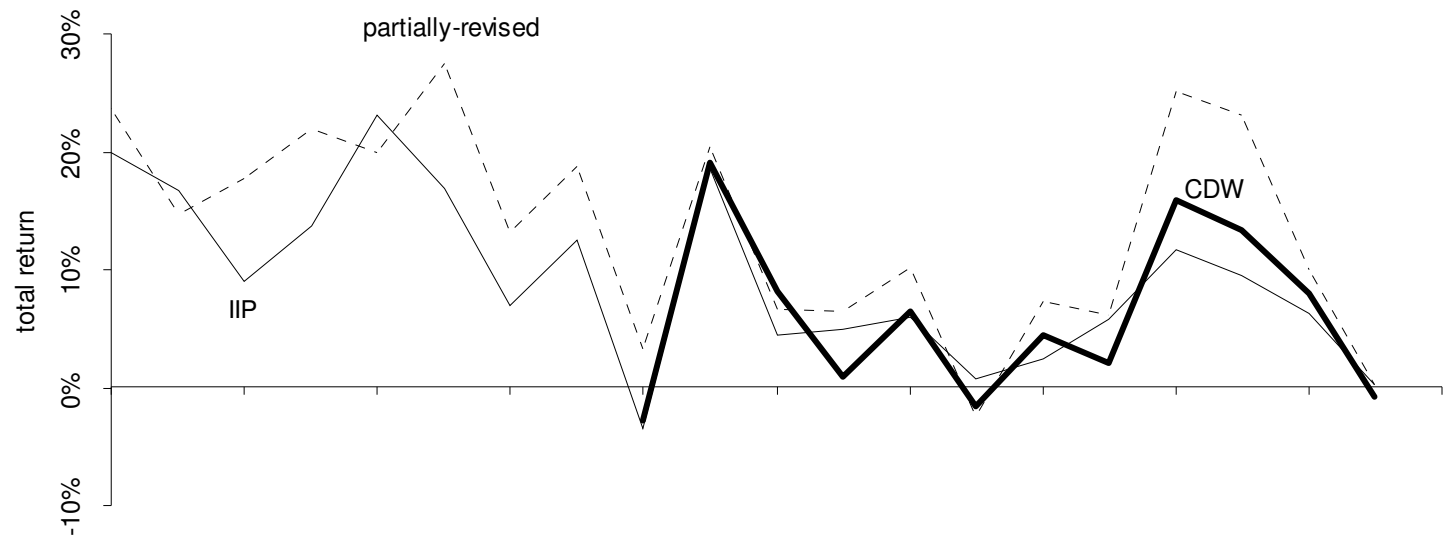

U.S. Holdings of Foreign Equity

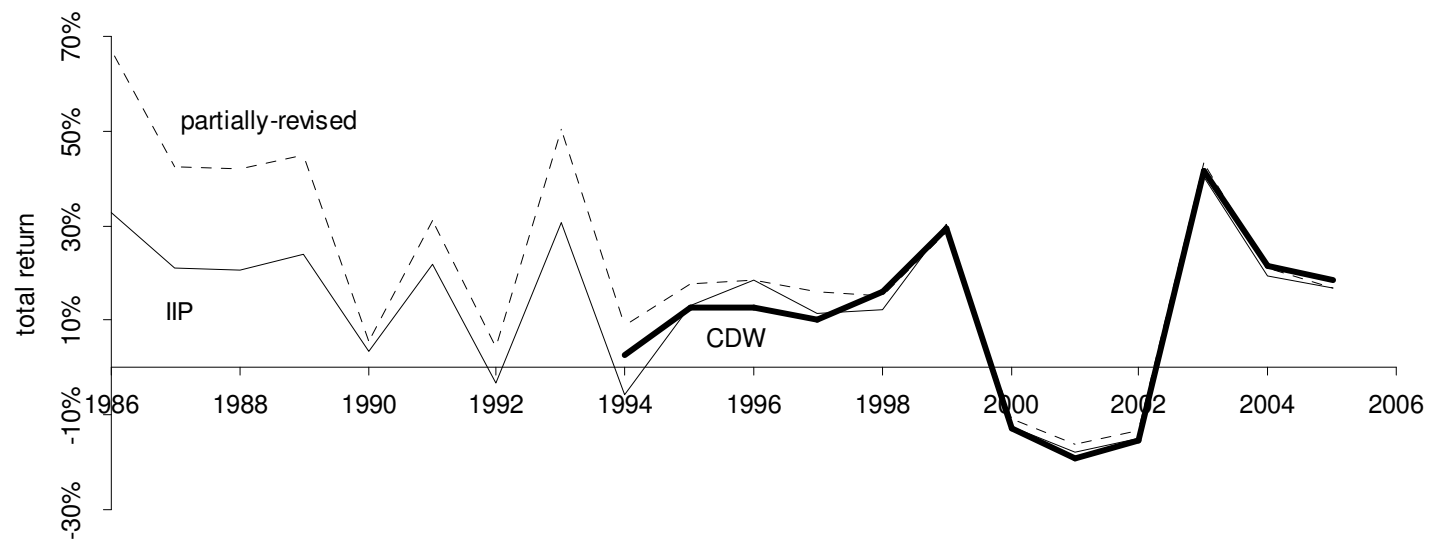




\section{Figure 4}

\section{Total returns on foreign holdings of U.S. bonds and equity}

In the IIP method capital gains are implied using the valuation adjustments due to price and exchange-rate changes reported on each annual IIP. We add the relevant income as reported to the IMF by BEA to the capital gains as estimated above. These total returns are divided by the IIP position at the start of the year, plus half of the year's IIP flows. In the partially-revised method, capital gains implied from the revised position and flow series available on the BEA website. For each year, the implied capital gain is the change in the revised position from the start of the year to the end of the year, less the revised flows that occur during the year and the valuation adjustments from other changes reported on the IIP. The same income series is added. These total returns are divided by the revised position at the start of the year, plus half of the year's revised flows. The CDW total return is the annual compound return computed using our position estimates and returns.

Foreign Holdings of U.S. Bonds

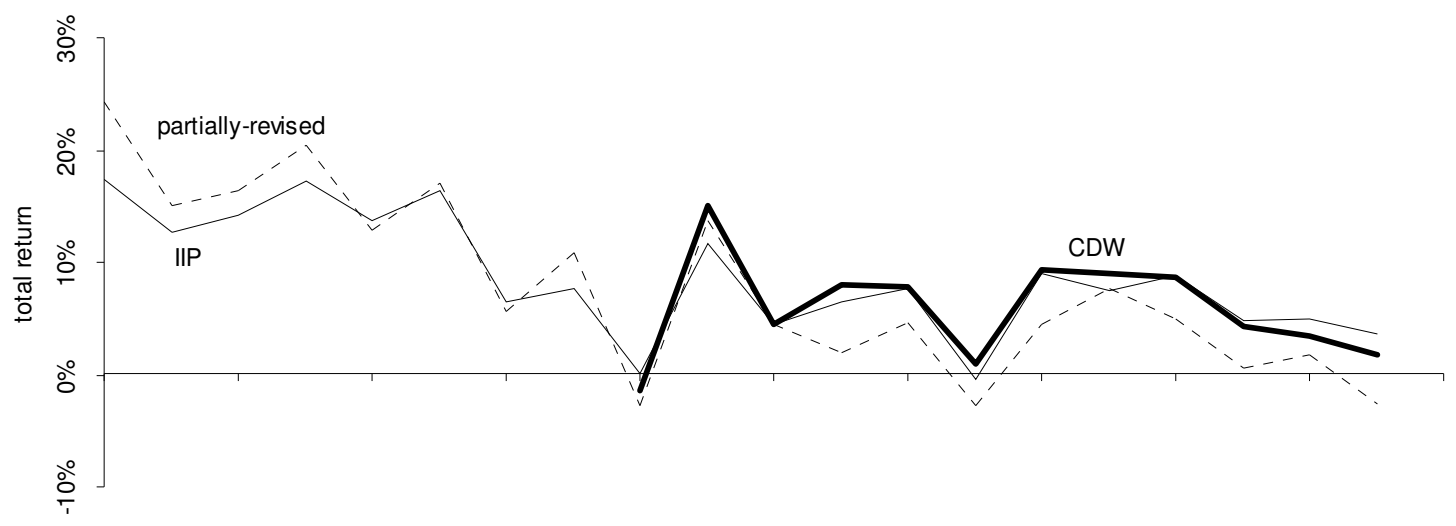

Foreign Holdings of U.S. Equity

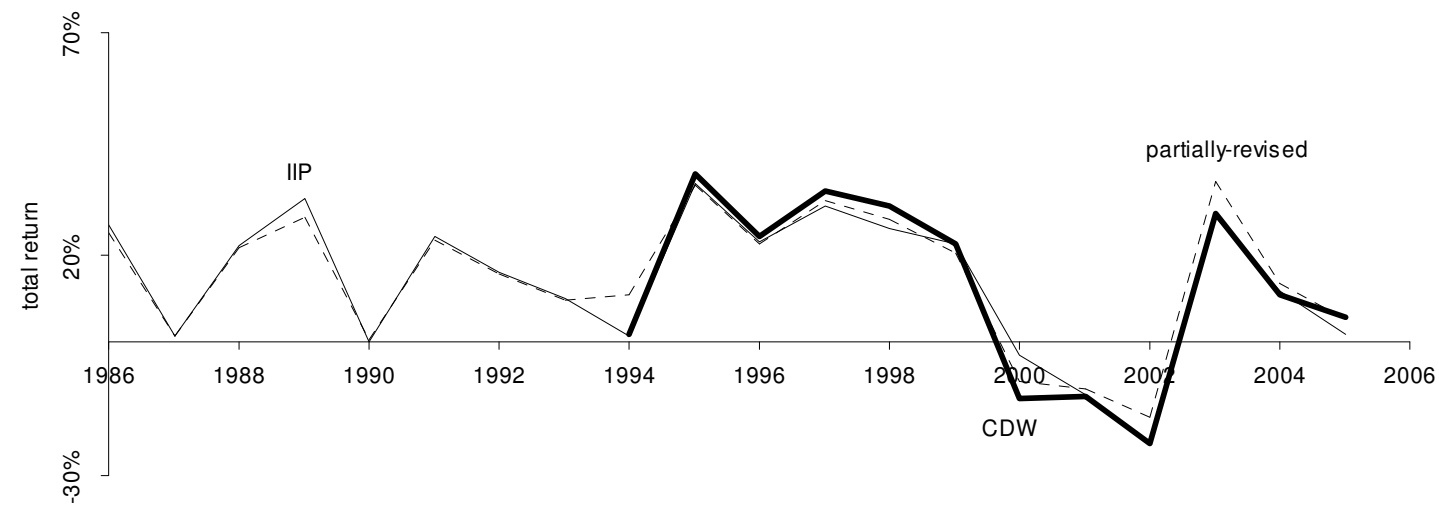

